\title{
The Management and Organizational Practices Survey (MOPS): An Overview*
}

\author{
by
}

\section{Catherine Buffington \\ U.S. Census Bureau}

\author{
Lucia Foster \\ U.S. Census Bureau
}

Ron Jarmin

U.S. Census Bureau

\section{Scott Ohlmacher \\ U.S. Census Bureau, University of Maryland}

\begin{abstract}
CES 16-28
June, 2016

The research program of the Center for Economic Studies (CES) produces a wide range of economic analyses to improve the statistical programs of the U.S. Census Bureau. Many of these analyses take the form of CES research papers. The papers have not undergone the review accorded Census Bureau publications and no endorsement should be inferred. Any opinions and conclusions expressed herein are those of the author(s) and do not necessarily represent the views of the U.S. Census Bureau. All results have been reviewed to ensure that no confidential information is disclosed. Republication in whole or part must be cleared with the authors.

To obtain information about the series, see www.census.gov/ces or contact J. David Brown, Editor, Discussion Papers, U.S. Census Bureau, Center for Economic Studies 5K034A, 4600 Silver Hill Road, Washington, DC 20233, CES.Papers.List@census.gov. To subscribe to the series, please click here.
\end{abstract}




\begin{abstract}
Understanding productivity and business dynamics requires measuring production outputs and inputs. Through its surveys and use of administrative data, the Census Bureau collects information on production outputs and inputs including labor, capital, energy, and materials. With the introduction of the Management and Organizational Practices Survey (MOPS), the Census Bureau added information on another component of production: management. It has long been hypothesized that management is an important component of firm success, but until recently the study of management was confined to hypotheses, anecdotes, and case studies. Building upon the work of Bloom and Van Reenen (2007), the first-ever large scale survey of management practices in the United States, the MOPS, was conducted by the Census Bureau for 2010. A second, enhanced version of the MOPS is being conducted for 2015. The enhancement includes two new topics related to management: data and decision making (DDD) and uncertainty. As information technology has expanded plants are increasingly able to utilize data in their decision making. Structured management practices have been found to be complementary to DDD in earlier studies. Uncertainty has policy implications because uncertainty is found to be associated with reduced investment and employment. Uncertainty also plays a role in the targeting component of management.
\end{abstract}

\footnotetext{
*Any opinions and conclusions expressed herein are those of the authors and do not necessarily represent the views of the U.S. Census Bureau. All results have been reviewed to ensure that no confidential information is disclosed. The MOPS was developed as a partnership between the Census Bureau and an external research team that includes Nick Bloom (Stanford), Erik Brynjolfsson (MIT), and John Van Reenen (LSE). The work of this team for MOPS2010 was supported by a grant from the National Science Foundation (NSF) and through administrative support from the National Bureau of Economic Research (NBER). The work for MOPS2015 was supported by grants from NSF, NBER, the Kauffman Foundation, and the Sloan Foundation. We thank Julius Smith of the Economy-Wide Division for his review of this paper ensuring that we have appropriately described the work.
} 


\section{Introduction}

The important role of management in the success of firms has long been stressed by academics in business and management, the media, and consultants, but most evidence has been anecdotal or based primarily on case studies. We describe one of the innovative steps forward in measuring management practices: the development and fielding of the first ever large-scale survey of management in the United States, the Management and Organizational Practices Survey (MOPS). The MOPS was developed as a partnership between the Census Bureau and an external research team of Nick Bloom (Stanford), Erik Brynjolfsson (MIT), and John Van Reenen (LSE), and later Steven Davis (University of Chicago) and Kristina McElheran (University of Toronto), and was sent to about 40,000 manufacturing establishments in 2011 and 2016. In this paper, we provide the background and motivation for developing the MOPS by describing the existing empirical literature on management practices, uncertainty, and data and decision making.

Already the MOPS has had wide-ranging impacts on the study of management practices worldwide, as questions based on the MOPS have been or will soon be issued as part of censuses in Canada, Germany, Pakistan, Japan, Australia, and the United Kingdom (Haltom and Bloom, 2014). The statistical agencies of Pakistan and Mexico have issued surveys that were adapted from the MOPS, although these surveys were conducted face-to-face rather than with paper instruments or electronically due to the fact that mail and e-mail were considered unreliable for contacting firms (Bloom, Lemos, Sadun, Scur, and Van Reenen; 2016).

While economists have been interested in the structure of the firm since at least the birth of the modern profession, ${ }^{1}$ it has only been in the post-war period that management has been considered explicitly in the study of firms. Early "managerial” models of the firm (Marris, 1964) focus on principal-agent problems, wherein a manager of a firm may seek to solve a different objective than her profit-maximizing employer. A small theoretical literature developed around a more robust model of role of management in firm structure starting in the early 1990's, but meaningful empirical studies of the role of management began to supplement these early theories only much later.

The theoretical literature on management that developed starting with Radner (1992) largely focused on incorporating the anecdotal evidence available in the business press and aggregate data into models of firm structure. Radner's (1992) interest in management stems largely from the observation that the growing number of large firms must require a more complex internal structure than the simple model of a profit-maximizing agent, or even a principle-agent model, allows. While Radner's (1992) motivations are not rooted in extensive empirical study of the role of management, this small literature has had far-reaching

\footnotetext{
${ }^{1}$ Syverson (2011) notes that academic writing on the importance of management for profitability dates back at least to Francis Walker (1887).
} 
implications, including motivation for macroeconomic models of rational inattention (Adam, 2007). Milgrom and Roberts (1990) propose a theoretical model of technological adoption that exhibits complementarities with changes in work practices and firm organization.

Recent findings on productivity have shown that there is significant and persistent dispersion of productivity across firms and even establishments that can only partially be explained by differences in inputs (Syverson, 2004), production technologies, price heterogeneity (Foster, Haltiwanger, and Syverson; 2008), and idiosyncratic shocks (Hsieh and Klenow, 2009). Based on the pre-existing theoretical research and anecdotal evidence regarding the importance of management practices, the hypothesis was put forward that perhaps management practices could account for some of the firm- and establishment-level heterogeneity in productivity.

Unlike these studies of firm- and establishment-level heterogeneity in productivity, which were made possible by the availability of representative or even population-level microdata from government sources, empirical studies of management were virtually non-existent until ten years ago. Syverson (2011) goes so far as to state that "perhaps no potential driver of productivity differences has seen a higher ratio of speculation to actual empirical study." Several recent studies have begun to alter this ratio, however, by creative uses of existing datasets.

Bertrand and Schoar (2003) use publically available data to match CEOs to firm performance data and find that demographic data about the CEOs predict management style. Ichniowski, Shaw, and Prennushi (1997) and Bartel, Ichniowski, and Shaw (2007) examine the impact of changing management practices on productivity in industry-specific samples of steel finishing plants and valve manufacturing, respectively. Ichniowski, Shaw, and Prennushi (1997) and Bartel, Ichniowski, and Shaw (2007) develop specific surveys of the human resource management practices for their respective samples; the latter also considers complementary IT investment. Acemoglu, Aghion, Lelarge, Van Reenen, and Zilibotti (2007) use measures of decentralization from two French data sets (Changements Organisationnels et Informatisation and Enquête Response) and a British data set (Workplace Employee Relations Survey) as proxies for delegation of decision making to managers. Related work by McElheran (2014) links the private Harte Hanks Computer Intelligence database to performance data from the 1997 Census of Manufacturers to examine decentralization of decision making within multi-unit firms.

In addition, a sizeable literature in the field of development economics has taken shape over the past five years focusing on the business training of microenterprises. This literature is primarily experimental in nature, offering business training to selected entrepreneurs, with mixed results. ${ }^{2}$ Similarly, Bloom, Eifert, Mahajan, McKenzie, and Roberts (2013) conducted a field

\footnotetext{
${ }^{2}$ See Karlan, Knight, and Udry (2012) and McKenzie and Woodruff (2012) for surveys of this literature. De Mel, McKenzie, and Woodruff (2014) also constructed a survey tool to gauge the existing management skills of entrepreneurs in Sri Lanka. The instrument can be found at http://www2.warwick.ac.uk/fac/soc/economics/staff/cwoodruff/data.
} 
experiment on 17 Indian textile firms having between 100 and 1,000 employees wherein the experimental firms were given management training, and performance was extensively monitored during and after the training period.

More ambitious direct measurement efforts have also taken shape. Several large-scale, multi-industry surveys were recently developed and administered. One of these, the World Management Survey (WMS), is of especial interest since it has served as a starting point of a sort for the MOPS. The WMS started in 2004, has run extensive double-blind telephone interviews on management practices with over 11,300 organizations in manufacturing across 34 countries between 2004 and 2014, and its methodology has been extended to samples in the retail, education, and healthcare industries in that time. As detailed below, the WMS has been adapted by international organizations for a survey and Statistics Canada has also developed two related surveys.

The paper proceeds as follows: Section 2 provides an overview of existing management surveys, Section 3 describes the core content of the MOPS, Section 4 discusses data and decision making, Section 5 discusses uncertainty, and Section 6 provides some discussion about future directions and concludes.

\section{Existing Management Surveys and Research}

Management practices have long been used as an explanation for the residual firm- and establishment-level heterogeneity in productivity that could not be explained by other, more measurable factors, even in the absence of strong empirical support. However, increasingly economists and government agencies have conducted surveys in an effort to measure management practices. Tables 1 and 2 provide an overview of these surveys; we discuss each in turn below.

The most widely cited empirical study of management at this time, the WMS, uses 18question telephone interviews to gather evidence regarding the importance of management practices. A summary of the practices of the WMS is offered in Bloom, Lemos, Sadun, Scur, and Van Reenen (2014) and a synopsis is given here. ${ }^{3}$ The WMS hires students in Master of Business Administration (MBA) or similar programs to call mid-level managers of firms in manufacturing, healthcare, education, and retail in 20 countries. Each interview is conducted in the native language of the interviewee, and the calls last 45 minutes on average. The interview questions are open-ended, and then the interviewers score the responses on a scale from one (worst) to five (best).

The interviewee is not aware that the responses are scored, nor is the interviewer provided information about the firm's performance when conducting the interview; moreover,

\footnotetext{
${ }^{3}$ For a detailed methodology, to view the survey instruments, or to access WMS data, visit worldmanagementsurvey.org.
} 
the sample firms are chosen so that the interviewer is unlikely to have prior knowledge of the firm. The firms' performance and financial data are obtained from independent sources. The interviewees are randomly selected from the population of all medium-sized firms in the given industry and country; that is manufacturing and retail firms that have 50-500 employees, hospitals that deliver acute care, and schools that educate 15-year-old students.

The questions asked of the interviewee fall into three categories: monitoring, targeting, and incentives/personnel management. The questions on monitoring ask the extent to which firms measure performance within the firm and use that data (if collected) to improve performance. The questions on targeting attempt to gauge how well firms set forward-looking goals and course correct if those goals are not met. Incentives/personnel management questions examine how employees are promoted, rewarded, and retained, or alternately reprimanded and dismissed.

Bloom and Van Reenen (2007) present the first results of the WMS finding that greater implementation of "structured management practices" -- that is, increased monitoring of firm activity, implementation of clear targeting practices, and the presence of strong incentives for achieving the establishment's targets -- is associated with higher productivity, profitability, and survival rates. They also compare cross-country results and find that U.S. firms generally implement more structured management practices than European firms, although there remain high levels of within-country dispersion of practices. Poor management practices are frequently associated with weaker competitive pressures and firms practicing primogeniture.

Bloom, Sadun, and Van Reenen (2012b) examine the management practices of multinational firms and find that firms that exist across countries with high levels of trust tend to decentralize decision making. Establishments of multinational firms tend to have high levels of structured management practice implementation in general. Bloom, Sadun, and Van Reenen (2015b) find that private equity owned firms have more structured management practices than do government, family, or privately-owned firms, particularly in monitoring practices. Private equity firms are also more likely to be structured in a way that grants more autonomy to individual establishments relative to other types of firms.

Bloom, Lemos, Sadun, Scur, and Van Reenen (2014) note that there are high levels of dispersion in adoption of structured management practices for schools (Bloom, Lemos, Sadun, and Van Reenen; 2014) and hospitals (Bloom, Sadun, and Van Reenen; 2013), with governmentrun schools and hospitals generally having lower scores on structured management scores than their privately-owned counterparts. Other users of the WMS methodology have found a spectrum of adoption of structured management practices in fostering, adoption, and nursing homes (Delfgaauw, Dur, Propper, and Smith; 2011); tax agencies in OECD countries (Dohrmann and Pinshaw, 2009); public-private partnerships (Homkes, 2011); substance abuse clinics (McConnell, Hoffman, Quanbeck, and McCarty; 2009); UK university departments (McCormack, Propper, and Smith, 2013); tradable service firms in Ireland (McKinsey and 
Company, 2009); Nigerian civil service (Rasul and Rogger, 2013); and American hospitals and cardiac care units (McConnell, Lindrooth, Wholey, Maddox, and Bloom; 2013, 2016). Rasul and Rogger (2015) also find that ethnic diversity at public sector organizations in Nigeria is positively correlated with structured management practices. Rahaman and Al Zaman (2013) use the Bloom and Van Reenen (2007) WMS data set with Loan Pricing Corporation DealScan data to show that structured management practices are negatively correlated with interest rates on corporate loans and that firms with more structured practices are more likely to borrow from more reputable lenders than firms with less structured practices.

In 2008 and 2009, the European Bank for Reconstruction and Development and the World Bank adapted the WMS to conduct the Management, Organisation, and Innovation survey (MOI) to study management practices in 10 transition countries. Although the 12 questions on the MOI survey instrument were adapted from the WMS, the questions were closed rather than open-ended, and interviews were conducted face-to-face rather than over the telephone. Using MOI data, Bloom, Schweiger, and Van Reenen (2012) find that management scores in Central European transition countries are quite similar to management scores in Western Europe, while Central Asian transition countries trail other developing Asian countries in structured management practice adoption.

The National Employer Survey (NES), conducted by the Census Bureau over three waves (1993, 1997, and 2000), asked questions related to employees and employment, employee training, business characteristics, and equipment and technology. The NES had 3,358 respondents for 1993 and 5,465 respondents for 1997 (and a longitudinal component). ${ }^{4}$ Supplements on partnerships between employers and schools were conducted by telephone interview in 1996 and 1998. A third wave of the NES was run in 2000, sampling 2,825 establishments that responded to the second wave of the survey as well as 50 employees each for 225 matched establishments. The establishment component of the NES, which was a joint venture with the National Center for the Educational Quality of the Workforce, was conducted as a computer-aided telephone interview of plant managers.

Cappelli and Neumark (2001) use NES data and find weak evidence of a positive impact of increased decision making power for employees on productivity. Black and Lynch (2001) find that unionized establishments with increased worker decision making have higher productivity than do similar nonunion establishments and unionized firms with traditional decision making structures. Establishments with higher education levels are more productive than establishments with lower education levels, and establishments with more computer usage by non-managers are more productive than establishments that where non-managers are less likely to use computers.

Statistics Canada conducted the Workplace and Employee Survey (WES) annually on a representative sample of approximately 10,000 to 15,000 establishments between 1999 and 2006

\footnotetext{
${ }^{4}$ For a detailed description of the NES, see Cappelli (2002).
} 
that included questions on compensation, training, human resources practices, organizational change, performance, business strategy, innovation, and technology use. Statistics Canada also ran the Survey of Innovation and Business Strategy on roughly 4,000 and 8,000 establishments in 2010 and 2013, respectively. The establishments were drawn from fourteen industries as defined by the North American Industry Classification System (NAICS). The survey sought to gather information on monitoring, structure, use of advanced technology, human resource management, and other business strategies.

Statistics Canada's WES is conducted in two parts: a computer-aided phone survey is administered to employers and a telephone interview conducted with employee participants. ${ }^{5}$ The survey covered a longitudinal sample of establishments, with approximately 9,000 establishments selected in 1999, with new establishments gradually added (and naturally other establishments exiting), leading to a sample of approximately 15,000 units in 2005. The establishments are selected to be representative of workplaces in Canada. The employer survey consists of 50 questions divided into nine sections: workforce characteristics and job organization, compensation, training, human resources practices, collective bargaining, workplace performance, business strategy, innovation, and technology use.

The employee sample consists of no more than 24 randomly-selected employees per establishment, with an annual sample of about 20,000 workers. Employees are surveyed for two years, and then a new sample is drawn. The employee survey consists of 59 questions across ten categories: job characteristics, computers and other technologies, training and development, career-related training, employee participation, personal and family support programs, worker representation and industrial relations, compensation, work history/turnover, and demographics.

Yang, Kueng, and Hong (2015) use the employer component of the WES to show that adoption of structured management practices is strongly correlated with particular business strategies of for-profit firms. These strategies are: novelty, low-cost, and high-quality. Firms pursuing "novelty” strategies seek to provide a good or service that is unique in itself. Firms pursuing low-cost or high-quality strategies seek to compete on either cost or quality. Low-cost firms tend to delegate more to managers, whereas novelty firms tend to implement more autonomy for all workers. Both high-quality and novelty firms are likely to implement structured management practices related to incentives. Hong, Kueng, and Yang (2015) also use the employer component of the WES to show that performance-based pay systems are complementary to decentralization of decision making from principals to managers.

The Survey of Innovation and Business Strategy (SIBS), also from Statistics Canada, takes representative samples of approximately 4,000 and 8,000 establishments in 14 NAICS industries in 2010 and 2012, respectively. ${ }^{6}$ The survey consisted of over 100 questions on

\footnotetext{
${ }^{5}$ The 2006 survey consists only of the employer component. For more information on the WES, visit www23.statcan.gc.ca/imdb/p2SV.pl?Function=getSurvey\&SDDS=2615.

${ }^{6}$ For more information on the SIBS, visit www23.statcan.gc.ca/imdb/p2SV.pl?Function=getSurvey\&SDDS=5171.
} 
business strategies and monitoring, enterprise structure, operational activities, relocation of activities in to and out of Canada, sales, relationships with suppliers, technology usage, innovation, structured management practices, and use of government support programs. This survey was sent to establishments both as a paper and an electronic survey form.

Brouillette and Ershov (2014) use the SIBS to construct a measure of management practices that is analogous to the index created by Bloom and Van Reenen (2007) and find that larger firms implement more structured practices. They find that this measure is positively correlated with a measure of business innovation for all sectors, but only in manufacturing industries are structured practices positively and significantly correlated with sales and profits.

\section{Management and Organizational Practices Survey}

The Management and Organizational Practices Survey (MOPS) collects information on targeting, monitoring and incentives managerial practices; the locus of decision making within the organizational structure of the firm to which the establishment belongs; and related background information from a sample of U.S. manufacturing establishments. ${ }^{7}$ The 2010 survey consisted of 37 questions in three sections: management practices, organization, and background characteristics. The 2015 survey consists of 47 questions covering the original (modified) sections and new sections on data and decision making and uncertainty. In this section, we discuss the overall sample and collection strategies and the three common sections. Sections 4 and 5 discuss the new sections. Appendices B and C contain the complete instruments for 2010 and 2015 respectively.

\subsection{Sampling, Collection, and Dissemination Strategies}

The sample for the MOPS consists of the approximately 50,000 establishments in the Annual Survey of Manufacturers (ASM) mailout sample. The mailout sample for the ASM is redesigned at 5-year intervals beginning the second survey year subsequent to the Economic Census. (The Economic Census is conducted every five years in years ending in '2' or '7.') For the 2009 and 2014 survey years, a new probability sample was selected from a frame of approximately 117,000 manufacturing establishments of multi-location companies and large single-establishment companies in the 2007 and 2012 Economic Census, which surveys establishments with paid employees located in the United States. Using the Census Bureau's Business Register, the mailout sample was supplemented annually by new establishments, which have paid employees, are located in the United States, and entered business in 2008 - 2010 or $2013-2015 .^{8}$

\footnotetext{
${ }^{7}$ The Census Bureau's informational website on MOPS can be found at www.census.gov/mcd/mops/index.html.

${ }^{8}$ This paragraph is the official methodological documentation for the 2010 MOPS, which can be found at https://www.census.gov/mcd/mops/how_the_data_are_collected/index.html. The certainty category slightly differs over industries. For more details on the ASM sample design see: http://www.census.gov/programssurveys/asm/technical-documentation/methodology.html
} 
The MOPS is conducted using paper and electronic survey instruments; the respondent may select the reporting mode. The MOPS is sent in the spring of the year after the reference year (April 2011 for MOPS 2010, May 2016 for MOPS 2015). Most Census Bureau surveys, including the ASM, are mailed to the firm's business address in the BR. For single-establishment firms, this is the business mailing address. ${ }^{9}$ For multi-unit firms, forms for all establishments in the sample are usually grouped and sent to the business mailing address, which is often the firm's headquarters, with instructions for the survey coordinator to distribute forms to the respondent plants as necessary. ${ }^{10}$

Because the MOPS asks respondents about practices that may vary across plants within a multi-unit firm and information about those practices may not be known at the firm level, the MOPS follows a unique mail strategy. For plants in multi-unit firms, the MOPS is mailed to the establishment physical address of the plant rather than to the firm's business address. In the absence of a physical address for the establishment, the BR is populated with the firm's business address. If the form is returned by the U.S. Postal Service as "undeliverable as addressed," it is then re-mailed to the firm business address.

An important feature of the MOPS is that it can be linked with little effort to Census Bureau data sets on plant-level outcomes. Since every establishment in the MOPS sample is also in the ASM sample, the results of MOPS can be linked with near certainty to annual performance data at the plant level, including outcomes on sales, shipments, payroll, employment, inventories, capital expenditure, and more for the corresponding ASM panel. ${ }^{11}$ Matching the MOPS to the Longitudinal Business Dataset (LBD) enables longitudinal research on establishment-level management practices and allows researchers to link MOPS data to, e.g., the quinquennial Census of Manufacturers (sent to all manufacturing establishments for years ending in ' 2 ' or '7’).

\section{Dissemination Strategy}

Raw data from the MOPS 2010 is available to qualified researchers on approved projects through the Federal Statistical Research Data Center (FSRDC) network. Once the MOPS 2015 collection is complete and the data has been processed, the raw data for the MOPS 2015 will also be available in the FSRDCs. For the MOPS 2015, the Census Bureau plans to release official tables using the data for management questions 1-16. Planned tables will provide aggregated results by subsector, state, plant employment size, and plant age, as well as question-level

\footnotetext{
${ }^{9}$ This address may or may not be the physical location of the establishment. It can be and administrative office, colocated with the plant or not.

${ }^{10}$ For respondents who prefer to answer surveys online, a letter is mailed to the enterprise address with login information. For multi-unit firms, the survey director at the firm distributes the login information to respondents at various plants as necessary.

${ }^{11}$ The ASM sample is updated over the course of the sample period to reflect establishment openings and closures, and thus not all establishments will be matched to the ASM for all years between 2009 and 2013. Similarly, nonresponse issues may prevent some establishments from being matched.
} 
statistics, subject to review. Statistics from MOPS 2010 were released via a press release and a detailed working paper (Bloom, Brynjolfsson, Foster, Jarmin, Saporta-Eksten, and Van Reenen; 2013).

Results of Collection in 2010

The MOPS 2010 had a total returned sample of approximately 37,000 establishments (a response rate of 78\%), making it by far the largest panel of establishments surveyed about management practices to date. For MOPS 2010, 58.4\% of respondents answered the survey electronically and the remaining $41.6 \%$ returned a paper form. Establishments in the sample were mailed the MOPS form, instructions, and a cover letter in April 2011. After approximately two months, establishments that had received the package but not yet responded were again sent the form, instructions, and cover letter. Due to a processing error, some respondents received this follow-up despite having already responded. After approximately another month, a follow-up letter was sent to establishments who had not yet responded. A round of telephone follow-ups was completed between September 2011 and January 2012.

\subsection{Developing Content}

The 2010 MOPS was developed using the WMS and existing Census Bureau collections as a starting point. In order to capture some of the dynamics of these core management practices, most questions on the MOPS are asked with two points of reference; respondents are asked to report their responses for the past year (e.g., 2015) and to look backwards and respond for five years earlier (e.g., 2010).

The U.S. Census Bureau's quality standards require that all data collection instruments must be tested and refined to ensure that the instrument can be understood and answered and does not cause undue burden for the respondents. ${ }^{12}$ One method of pre-testing a survey instrument is through expert review, which was conducted early in the development of the original MOPS survey and for its revised content. Another method of pre-testing is via cognitive interviews. Cognitive interviews are used to understand the respondents' thought processes as they work through the instrument and to use that knowledge to improve the survey questions. The 2010 and 2015 MOPS survey instruments were tested and refined based on the results of cognitive interviews, as well as usability testing to ensure that the instrument was functional for respondents.

\subsection{Measuring Management Practices}

The sixteen questions in the "Management Practices" section of the MOPS deal primarily with the structured management practices also covered by the WMS: namely, how activity is monitored, how targets for production and other monitored performance indicators are set, and how achievement of those targets is incentivized. The five monitoring questions concern the

\footnotetext{
${ }^{12}$ The specific standard is A2. For more information on the Census Bureau's quality standards, see http://www.census.gov/econ/aces/quality_standards.pdf
} 
collection and use of information to monitor production. For example, how many key performance indicators were monitored at this establishment? The three targets questions concern the nature of targets and their integration. For example, who was aware of production targets at this establishment? The eight incentive questions concern whether personnel practices provide incentives to workers and managers. For example, when was an under-performing manager reassigned or dismissed? The sixteen questions on management practices were unchanged between the 2010 and 2015 instruments to maximize comparability.

\subsection{Measuring Organization}

The original "Organization" section had thirteen questions that covered the level of decision making, span of control, and data and decision making. The five questions on the level of decision making concern whether resource (personnel and capital) and output (marketing, pricing) decisions are made at the establishment or headquarters. For example, where were decisions on new product introductions made? Three questions concern the structure of the organization. For example, who prioritized or allocated tasks to production workers at this establishment? The three remaining questions include two questions about data and decision making and one question about sources of information about management practices. For example, what best describes the use of data to support decision making at this establishment?

The "Organization" section was modified for the 2015 MOPS and now only includes seven questions. The three questions concerning structure were dropped: respondents are no longer asked for the number of employees that report directly to the plant manager, the number of direct report layers at the establishment, or who allocates tasks to production workers. The two questions on data and decision making were moved to a new expanded section (described in Section 4 below) and the question about the sources of information about management practices was dropped.

\subsection{Measuring Background Characteristics}

The questions in the "Background Characteristics" section cover both the establishment and the respondent. There were 8 background questions in 2010. The five establishment questions covered the number of managers and employees, their college education, and the prevalence of a union. The two respondent questions asked for seniority and tenure. The final question is a certification question for the instrument. ${ }^{13}$

The MOPS 2015 includes a revised the background section, with two questions dropped and four questions added. These questions concerned the level of seniority of the respondent and the number of employees at the establishment (the latter is collected by the ASM). The first two

\footnotetext{
${ }^{13}$ The certification question asks the respondent for her name, title, and contact information, as well as the time frame covered by the survey and the date that the survey was completed. This question is standard on Census forms. Bloom, Brynjolfsson, Foster, Jarmin, Saporta-Eksten, and Van Reenen (2013) use some information from the Certification as noise controls, and this question was used during processing to evaluate duplicate responses.
} 
questions added to the MOPS 2015 concern business strategies and production technologies. The second two additional questions concern the firm to which the establishment belongs.

For MOPS 2015, respondents are asked about changes in usage of the labor force; respondents are asked to estimate shares of workers who worked part-time, shares of workers who worked flexible hours, shares of workers who worked from home one or more day per week, and shares of workers who were cross-trained. This question will enable researchers to study the complementarities between management practices and labor practices in the U.S. as Yang, Kueng, and Hong (2015) find for Canadian firms.

Structured management practices might be complementary to a more flexible labor force, or more structure on monitoring, targeting, and incentives may prevent such flexible arrangements from being made. Furthermore, these human resources practices are interesting in themselves for how they describe the relationship between employees and their workplaces. The 2015 MOPS will provide information on work-life balance that could be useful to both researchers and policymakers.

Respondents are also asked whether their production can be best described as "job shop," "batch production," “cellular manufacturing," "continuous flow (other than cellular manufacturing),” or "research \& development or prototyping.” In contrast with the view of management taken by most of the empirical literature discussed above that more structured management practices can be institutional and make firms more productive, the organizational economics literature, including Gibbons and Henderson (2013) and Roberts and Saloner (2013), tends to emphasize management as a relational concept. That is, management practices must be tailored to the unique strategic and interpersonal needs of each establishment.

Bloom, Sadun, and Van Reenen (2015a) argue that empirical results on management practices are consistent with structured management practices being a technology that firms can adopt. Introducing this new question on production technologies will allow researchers to further test the "management as a technology" model of Bloom, Sadun, and Van Reenen (2015a) against the "management as design" hypothesis of Gibbons and Henderson (2013) and others. Although Bloom, Brynjolfsson, Foster, Jarmin, Saporta-Eksten, and Van Reenen (2013) control for industry-level fixed effects in their research, type of production may not be perfectly correlated with industry, and may provide additional insight into the relationship between management practices and outcomes.

Respondents are asked whether or not the firm is majority-owned by its founder(s) or members of a founder's family, and if it is, whether or not a founder or a member of a founder's family currently serves the firm as CEO. This will enable future research on primogeniture to compare with Bloom and Van Reenen (2007).

The final additional question concerns whether the establishment is a part of a firm with production establishments in countries other than the United States. This enables research on the 
impact of multinational status on management practices, and is useful variable for many of the projects undertaken within the Census Bureau and the network of Federal Statistical Research Data Centers, even those that are not specifically focused on management and organizational practices, expanding the value of the MOPS for the statistical community, policy makers, and academics. The organizational question on the location of the firm's headquarters, which was present on MOPS 2010, has been enhanced to include a write-in box for the state or country in which the firm's headquarters was located, which serves as a useful complement to this new question, as management and organizational practices may be country (or even state) dependent.

\subsection{Measuring Dynamics}

The addition of a second generation of the MOPS will introduce interesting dynamics between and across the two collections of the survey. MOPS 2010 is the first survey of establishment-level management practices across time by virtue of including a retrospective component of nearly every question. The longitudinal component of MOPS 2010 relies solely on the recall of the respondent. ${ }^{14}$ As a result, there could be concerns about recall bias and therefore about the quality of the responses for 2005. MOPS 2015 includes a similar recall component for 2010. By comparing the recall responses for 2010 on MOPS 2015 to the responses for 2010 from MOPS 2010, one will be able to establish some measure of the quality of the responses to recall questions on structured management practices. Thus, the longitudinal benefit of reissuing the MOPS survey for 2015 extends beyond adding one additional time period to the data, but could actually establish the quality of existing data for 2005.

As noted above, Bloom, Brynjolfsson, Foster, Jarmin, Saporta-Eksten, and Van Reenen (2013) find the average management score for 2010 is higher than the average reported score for 2005, with much of that growth coming from an increase in monitoring practices. This finding supports the work by Bresnahan, Brynjolfsson, and Hitt (2002) and Aral, Brynjolfsson, and Wu (2012) that finds that IT adoption and structured management practices are complementary. The relationship between technology adoption and structured management practice adoption is fertile ground for future research that is only possible with the recall data and repeated collection of the MOPS.

Furthermore, if structured management practices truly have a causal impact on establishment performance, a logical question is "How do establishments change their levels of implementation of structured management practices?” In order to answer this question, one must have a data set that includes a longitudinal component. This allows researchers to examine how management practices are adopted over time. By adding an additional panel for 2015, MOPS 2015 allows for increased study of the dynamics of management practices in U.S. manufacturing industries.

\footnotetext{
${ }^{14}$ Horvath (1982) examines the effects of asking individuals about unemployment spells on more than one occasion and finds that there are meaningful discrepancies.
} 
To this point, the existing surveys of management practices have lacked a strong longitudinal component. Although the WMS is long-running, each wave of the survey has focused on expanding the scope of the research across countries rather than across time. The WMS consists of five major waves in 2004, 2006, 2010, 2013, and 2014. All firms in the 2004 sample were re-contacted in 2006 in addition to firms that had not been previously contacted. Likewise, the 2010 sample re-contacted the firms from the 2006 sample, but without adding new firms to the sample. The 2014 sample also re-contacted panel firms from 2013. (Bloom, Sadun, and Van Reenen; 2015a) ${ }^{15}$

It is important to note that because the WMS sample is generated at the firm-level, the panels generally reflect the responses of different managers at possibly different establishments. The resampling of firms between 2006 and 2010 yielded a correlation of 0.427 , which could be a result of some combination of within-firm heterogeneity, changes in practices over time, and/or respondent bias. Additionally, the MOI deliberately resampled 404 firms (with possibly different plants and/or different respondents) from the WMS for the purpose of validating the MOI instrument and yielded a correlation of 0.298 with two to three years having elapsed between the two interviews. (Bloom, Schweiger, and Van Reenen; 2012)

MOPS 2010 is conducted at the establishment-level, and the sample includes establishments of multi-unit firms. Bloom, Brynjolfsson, Foster, Jarmin, Patnaik, SaportaEksten, and Van Reenen (2016) find that half of the variation in management practices in the MOPS sample can be accounted for by differences in management practices across establishments within the same firm. The WMS did perform some internal validation by resampling $5 \%$ of each sample using a second interviewer to contact a second plant manager within the firm. This sample of 222 firms yielded a correlation between first and second interviews in the same year of 0.51 . The difference is explained by some combination of withinfirm heterogeneity and survey measurement error. (Bloom, Sadun, and Van Reenen; 2015a)

\section{Data and Decision Making}

We start by providing motivation for the MOPS questions on data and decision making (two in 2010 and six in 2015) by reviewing the existing literature and research in this field. Part of the impetus for including management in theoretical economic models such as Radner (1992) or Adam (2007) is that managers may be essential for gathering and processing information. Indeed, two of the components of the structured management practices above, monitoring and targeting, can be described as a form of information processing. Management gathers information about production conditions both within and outside of the establishment (or firm)

\footnotetext{
${ }^{15}$ Bloom, Sadun, and Van Reenen (2015a) use a panel of 13,944 firm-year observations between 2004 and 2014 to generate a 5-year growth rate of management which is then used in a simulated method of moments (SMM) estimation of the adjustment costs associated with structured management practices. However, some portion of the data is interpolated because the interview is not conducted annually.
} 
and then uses that information to set targets and make adjustments to the production process. The degree of data collection performed by firms is a key component of this relationship.

The rise of information technologies (IT) has made it possible for establishments to utilize ever increasing amounts of data in their decision making, and Brynjolfsson and Mendelson (1993) argue that the increasing availability of data has necessitated the development and implementation of structured management practices. Much of the existing work in this field is focused on the implementation of information technologies. While IT and data and decision making (DDD) are clearly complementary, they are not necessarily proxies for one another. A firm could conceivably gather data for decision making without high levels of IT investment, while a firm that utilizes modern IT may not necessarily fully integrate DDD.

Bresnahan, Brynjolfsson, and Hitt (2002) use a combination of a telephone survey of 379 firms, computer capital data from Computer Intelligence InfoCorp, and input and output data from Compustat. ${ }^{16}$ The telephone survey included 14 questions related to the organization of the firm's workforce, which are neither fully orthogonal to nor entirely consistent with the definition of structured management practices given above. The survey measures uses of teams, dispersion of authority, and education. The authors find that IT implementation and workplace reorganizations focused on teamwork and individual authority are both positively correlated with productivity and have complementary effects when implemented together. Similarly, Aral, Brynjolfsson, and Wu (2012) find high levels of complementarities between IT implementation, implementation of performance pay, and human resource management practices that monitor performance and give employee feedback. Taken together, these three practices have a large positive impact on worker productivity in the 189 firms surveyed by a non-profit organization that educates firms on human resource practices that also purchased an IT system called Human Capital Management.

Bloom, Garicano, Sadun, and Van Reenen (2009) combine the WMS with a private software utilization data source called Harte-Hanks. They find that increased implementation of information technology leads to more decentralization in manufacturing firms, while implementation of communication technology leads to greater centralization.

The Census Bureau collected the Computer Network Use Supplement (CNUS) to the ASM sample in 1999. Like the MOPS, this data could be readily matched to high quality performance data from the ASM. Atrostic and Nguyen (2005) find that establishments that have computer networks have higher labor productivity than establishments that do not have computer networks. They find that moving from the $10^{\text {th }}$ to the $90^{\text {th }}$ percentile of computer network use was associated with a 7.2\% increase in labor productivity, as well as evidence that establishments with low labor productivity in earlier periods use the introduction of computer

\footnotetext{
${ }^{16}$ A detailed description of the data set is available in Brynjolfsson and Hitt (1997).
} 
networks to "catch up" with more productive establishments. Additionally the use of networks in 1999 was more likely for establishments of multi-unit firms than for single units.

Results on DDD are similar to those on structured management practices. Using a survey conducted on 330 large, publicly-traded firms in 2008, Brynjolfsson, Hitt, and Kim (2011) find that output and productivity are higher for firms that depend on data to make decisions than for other firms with similar levels of investment and IT usage. Using an instrumental variable method, they find that it seems likely that utilization of DDD leads to higher productivity, rather than it being the case that more productive firms are simply more able to then implement DDD.

Bloom, Sadun, and Van Reenen (2012a) use a modified version of the WMS survey instrument's questions on personnel management, as well as a private IT survey, accounting data, and a UK Office of National Statistics data set to show that personnel management practices are positively correlated with IT investment and productivity. They find that U.S. multinationals achieve higher productivity from IT investment than do non-U.S. multinationals or non-U.S. companies broadly. The difference in IT productivity is attributed to complementary investment in personnel management practices in U.S. multinationals. Bartel, Ichniowski, and Shaw (2007) also find that investment in IT is accompanied by changes in personnel management practices in the valve production industry.

As noted above, the MOPS 2010 included two questions in "Organization" that touched upon DDD; MOPS 2015 moves these two questions to the start of the new "Data and Decision Making” component of the survey. ${ }^{17}$ In effect, this does not affect the order of the questions, but only inserts a header above these two questions, and so the comparability of the 2010 and 2015 collections should not be adversely impacted due to question order bias. The two existing questions ask if data is available to establishments and if it is being used to make decisions when available, similar to the questions asked by Brynjolfsson, Hitt, and Kim (2011).

Using the questions from the management section of the MOPS 2010, Bloom, Brynjolfsson, Foster, Jarmin, Saporta-Eksten, and Van Reenen (2013) find that respondents report significant growth in data-driven monitoring practices between 2005 and 2010, which is a significant driver in overall improvement of management practices over that period, but they do not link this result to the two DDD questions. Brynjolfsson and McElheran (2016) use an index constructed from the monitoring questions and the two DDD questions on the 2010 MOPS to find that larger, older plants of multi-unit firms adopt DDD earlier and to a larger extent than smaller, single-unit firms. However, the single-unit firms exhibit a higher correlation with performance than similarly-sized firms that do not adopt DDD.

There are four new DDD questions on MOPS 2015. First, establishments are asked who chose what data was collected by the establishment. Second, respondents are asked to gauge how

\footnotetext{
${ }^{17}$ The new module is called "Data and Decision Making” rather than "Data-driven Decision Making” so as not to lead respondents to assign value to data utilization when it is not a part of their establishment's process.
} 
frequently four key data sources are used in the decision making process. The data sources referenced are production performance indicators from production technology or instruments, formal or informal feedback from managers, formal or informal feedback from non-managers, and outside data, which includes data from suppliers, customers, and/or outside data providers such as Federal statistical indicators. Third, MOPS 2015 also collects data on what types of decisions, namely new product design, demand forecasting, and supply chain management, are driven by data analysis and how frequently those decisions refer back to data. Fourth, respondents are asked about the reliance on predictive analytics.

As noted previously, two important components of structured management practices are targeting and monitoring. Monitoring is inherently coincidental, but targeting is a forwardlooking process. The DDD section will include a fourth new question on the frequency with which decisions are made using predictive analytics such as statistical models of demand or production. This will enhance the ability of researchers to study the sophistication of the management practices being implemented by establishments. The role of DDD in predictive analysis also connects DDD and management practices with the study of uncertainty, the second new section of questions in MOPS 2015 which we turn to next.

\section{Uncertainty}

The final new section of the MOPS concerns uncertainty. Here we give some background that led to the eight questions in the 2015 MOPS. Like management, "uncertainty" has long been a useful explanation for economic outcomes in the popular press, policymaking, and theoretical models. Knight (1921) defined uncertainty as the inability of a person to make a forecast about an upcoming event. In contrast to risk, where a person has some knowledge of an underlying probability distribution, uncertainty comes about when it is reasonably difficult to get a sense of the probability of outcomes, or even the entire outcome space. Because this definition of uncertainty involves unknown probabilities and outcomes, measuring the degree of uncertainty in the economy involves measuring the degree to which individuals are aware of unknown probability distributions.

This difficulty associated with measuring uncertainty has not stopped uncertainty from long being used as an explanation for economic outcomes. Bloom (2014) presents several key examples of the popular press suggesting that uncertainty over policy and growth has hindered investment and employment growth. For example, the Federal Open Market Committee attributed a slowdown in investment to firms' uncertainty about economic prospects in 2008, and the Chief Economist of the IMF Olivier Blanchard and then-Chair of the Council of Economic Advisors Christina Romer both cited uncertainty as a factor driving a reduction in demand in 2009. The theoretical literature allows for increasing uncertainty as an impetus for reduction in 
economic activity through several channels, including increasing risk premia (for example, Arellano, Bai, and Kehoe (2010)) and precautionary savings (Bansel and Yaron, 2004).

Bloom (2014) examines many of the common measures of uncertainty, which include stock market volatility, GDP volatility, variation between consensus estimates and realized values of economic indicators, the Federal Reserve Bank of Philadelphia's Survey of Professional Forecasters, and the number of appearances of the word "uncertainty" in newspaper articles or the Federal Reserve's Beige Book. A research team including Scott Baker, Nick Bloom, and Steven Davis compiles indices of policy uncertainty generated from newspaper articles for the U.S., Europe, Canada, China, India, Japan, and Russia at www.policyuncertainty.com. Their index for the U.S. also includes data on expiring tax code provisions and disagreement between professional forecasters (drawn from the Survey of Professional Forecasters).

Baker, Bloom, and Davis (2013, 2015) and Baker, Bloom, Canes-Wrone, Davis, and Rodden (2015) examine the measurement of policy uncertainty, its role in stock market fluctuations, and its potential sources, respectively. However, Jurado, Ludvigson, and Ng (2015) note that the use of proxies to measure uncertainty may be useful only under a limited set of circumstances. For instance, they note that "stock market volatility can change over time even if there is no change in uncertainty about economic fundamentals, if leverage changes, or if movements in risk aversion or sentiment are important drivers of asset market fluctuations.” (Jurado, Ludvigson, and Ng; 2015) As an alternative, Jurado, Ludvigson, and Ng (2015) use Markov chain Monte Carlo methods to generate a measure of uncertainty from a time series consisting of 132 mostly macroeconomic variables and 147 financial variables.

The aforementioned proxies of policy uncertainty have been widely used in finance, and have been presented in congressional and Federal Reserve testimony. ${ }^{18}$ Bloom (2009) uses stock market volatility to show that bad news uncertainty shocks are associated with reductions in hiring and investment. Similarly, Bloom, Bond, and Van Reenen (2007) use deviations in stock returns to show that uncertainty reduces investment. If one takes the view, as in Bloom, Sadun, and Van Reenen (2015a) that management is a technology, then adoption of management practices can be viewed as a form of investment. However, the relationship between uncertainty and adoption of structured management practices has been largely untested to this point.

Several surveys by central banks take the approach of directly asking households and businesses for their expectations over various economic outcomes. The Bank of Japan’s TANKAN is sent out to 210,000 large firms quarterly and can be answered by mail or online. ${ }^{19}$ Firms are asked to judge their views of business conditions, inventories, capacity, employment, finances, and other topics at the present, and then asked to give annual projections on sales, exports, exchange rates, profits, income, investment, and inflation. Similarly, The Bank of Italy's

\footnotetext{
${ }^{18}$ For a list of applications of this data, visit www.policyuncertainty.com/research.html.

${ }^{19}$ For more information on TANKAN, visit www.boj.or.jp/en/statistics/tk/index.htm.
} 
Survey on Inflation and Growth Expectations is issued annually and manufacturing firms are asked about investment levels for the current year, which includes a partial forecast. ${ }^{20}$ D'Aurizio and Iezzi (2010) use these qualitative responses to build a forecasting model of investment. The Federal Reserve Bank of Philadelphia also runs a monthly Business Outlook Survey (BOS) in which 100-125 manufacturing firms are asked only if certain economic indicators (orders, shipments, prices, employees, etc.) are expected to increase, decrease, or remain unchanged within the next six months. ${ }^{21}$

The Ifo Institute Center for Economic Studies in Munich has run the Ifo Business Climate Survey (IFO-BCS) that surveys between 2,500 and 5,000 German products (which cover 2,0004,000 continuing firms) on a monthly basis with consistent data running back to 1980 . Respondents are asked to characterize their expectations of business conditions as "more favorable," “unchanged,” or “more unfavorable.”22 Bachmann, Elstner, and Sims (2013) use both the BOS and IFO-BCS to show that adverse supply shocks tend to increase uncertainty, but uncertainty in the absence of shocks have only limited adverse effects on real activity.

The Federal Reserve Bank of Atlanta, in partnership with Steven Davis of the University of Chicago Booth School of Business and Nicholas Bloom of Stanford University, has created the Decision Maker Survey to measure firms' year-ahead expectations and associated uncertainties regarding changes in their costs, prices, profit margins, level of employment, capital investment, and sales revenue. The survey panel consists of a national sample of firms representing every sector of the economy (with the exception of agriculture and government) and a broad range of firm sizes. In addition, the Federal Reserve Bank of Atlanta runs the Business Inflation Expectations survey, which asks 300 firms monthly to assign probabilities to six potential outcomes for inflation over the next twelve months, ${ }^{23}$ and asks a pair of questions on its biannual Small Business Survey (SBS) on uncertainty. The SBS covers firms with fewer than 500 employees and asks respondents whether "uncertainty" as a broad concept is having a larger or smaller impact on the firm's decision making relative to six months prior, and then asks respondents to cite the primary source of uncertainty. ${ }^{24}$

The link between management and uncertainty is discussed in some of the theoretical literature, including Adam (2007) which uses management as a motivator for limited capacity for information processing. If managers are responsible for gathering and processing information and setting targets, then managers are responsible, in some sense, for monitoring uncertainty. Do

\footnotetext{
${ }^{20}$ For more information on the Survey on Inflation and Growth Expectations, visit www.bancaditalia.it/statistiche/tematiche/indagini-famiglie-imprese/aspettative-inflazione/index.html.

${ }^{21}$ For more information on the BOS, visit www.philadelphiafed.org/research-and-data/regional-economy/businessoutlook-survey/

${ }^{22}$ For more information on the IFO-BCS, visit www.cesifo-group.de/ifoHome/facts/Survey-Results/BusinessClimate.html.

${ }^{23}$ For more information on the Business Inflation Expectations survey, visit www.frbatlanta.org/research/inflationproject/bie.aspx

${ }^{24}$ For more information on the SBS, visit www.frbatlanta.org/research/small-business/survey.aspx.
} 
better management practices and more data-driven decision making lead to better forecasts and reduced uncertainty? Does the presence of uncertainty increase investment in management because of this effect? Or does uncertainty reduce investment in management practices due to precautionary savings on the part of the establishment? Limited research exists to this point on the role of management in the quality of forecasts, but Ben-David, Graham, and Harvey (2013) find that executives are often incorrect with regards to their forecasts of stock market distributions.

MOPS 2015 includes eight new questions on uncertainty. There are two uncertainty questions on each of the following four subjects: shipments, capital expenditure, employment, and the cost of materials, parts, containers, and packaging. The first question for each subject asks for an estimate of the value of the variable in question in 2015 as well as a partial forecast of 2016, which will be roughly one-third complete at the time that respondents receive the survey. The latter portion of these questions is in the vein of the Italian Survey on Inflation and Growth Expectations, while the former allows for a measure of the measurement error of the respondents relative to the $\mathrm{ASM}^{25}$

The second question asks respondents for five points of their possible distribution of possible outcomes at the plant for 2017 (lowest, low, middle, high, and highest) and the likelihood that they would assign to each outcome. Taken together these questions can be used to estimate the moments of the distributions of the variables in question, which provides a much richer measure of uncertainty than the proxies outlined above. ${ }^{26}$ Because this set of questions is somewhat abstract, the section is preceded by instructions with an example of how a hypothetical respondent might fill out a pair of uncertainty questions.

\section{Conclusions}

Management has long been used as a residual in the explanation of why performance differs across firms and establishments. While business schools and the popular press have emphasized the importance of particular management practices, only in the last ten years have economists devoted significant empirical study to management practices. As the largest single study of management practices and the first large-scale study of management in the United States, the MOPS is at the center of this burgeoning field of research.

\footnotetext{
${ }^{25}$ Note that the questions on employment ask for employment as of March 12 for consistency with the ASM. Since MOPS 2015 will be mailed in 2016, the question on employment in 2015 and 2016 will not include a forecasting component.

${ }^{26}$ The Census Bureau's annual Business R\&D and Innovation Survey (BRDIS) asks respondents for firm-level forecasts of R\&D expenditure for the year following the coverage year (which is the year in which the survey is completed). The BRDIS also includes similarly structured questions on forecasted foreign and domestic R\&D expenditure and the amount of R\&D expenditure paid for by others. More information on the BRDIS can be found on the Census Bureau's informational webpage:

http://www.census.gov/manufacturing/brdis/
} 
The research team (external researchers and Census researchers) published the first detailed results of the MOPS 2010 data in a CES working paper. ${ }^{27}$ Bloom, Brynjolfsson, Foster, Jarmin, Saporta-Eksten, and Van Reenen (2013) report findings that are consistent with the earlier work from the WMS. Firms that adopt more of the structured management practices related to monitoring, targeting, and incentives are more productive, more profitable, and grow faster than firms with lower levels of structured management practice adoption. They also find that there are high levels of dispersion in structured management practice adoption, with higher levels of adoption being found in the South and Midwest, in larger establishments, in establishments of large firms, in exporting establishments, and in establishments with more educated employees. Finally, the authors find that establishments generally report higher levels of implementation of structured management practices since 2005.

A second working paper was published including on preliminary results involving investment in IT. Bloom, Brynjolfsson, Foster, Jarmin, Patnaik, Saporta-Eksten, and Van Reenen (2014) utilize the linkages between MOPS and ASM performance data, as well as capital stock data from the Census of Manufacturers and link to Compustat data. They find that firms with higher management scores generally have higher rates of innovation, invest more heavily in IT, and have higher stock market valuations.

The second collection of the MOPS will enable us to better understand the dynamics of management practices. Moreover, the expanded version of the MOPS includes questions on two new subjects related to management: data and decision making and uncertainty. Because management is concerned at least in part with monitoring and setting forecasts, data collection and usage is an important complement to structured management practices. Furthermore, since targeting is at least in part forward-looking, structured management practices must also be related to the study of uncertainty. With its sixteen new questions (four on background, four on DDD, and eight on uncertainty), it will be exciting to see how the MOPS2015 adds to our understanding of management practices in the U.S.

\footnotetext{
${ }^{27}$ The first publication reporting any results from the MOPS2010 was a Census Bureau press release. See http://www.census.gov/newsroom/press-releases/2013/cb13-03.html.
} 


\section{References}

Acemoglu, Daron, Philippe Aghion, Claire Lelarge, John Van Reenen, and Fabrizio Zilibotti (2007), 'Technology, Information, and the Decentralization of the Firm,' Quarterly Journal of Economics, 122(4), 1759-1799.

Adam, Klaus (2007), 'Optimal Monetary Policy with Imperfect Common Knowledge,' Journal of Monetary Economics, 54(2), 267-301.

Aral, Sinan, Erik Brynjolfsson, and Lynn Wu (2012), 'Three-Way Complementarities: Performance Pay, Human Resource Analytics and Information Technology,' Management Science, 58(5), 843-859.

Arellano, Cristina, Yan Bai, and Patrick Kehoe (2010), 'Financial Markets and Fluctuations in Uncertainty,' Federal Reserve Bank of Minnesota Research Department Staff Report.

Atrostic, B.K., and Sang V. Nguyen (2005), 'IT and Productivity in US Manufacturing: Do Computer Networks Matter?’ Economic Inquiry, 43(3), 493-506.

Bachmann, Rudiger, Steffen Elstner, and Eric R. Sims (2013), 'Uncertainty and Economic Activity: Evidence from Business Survey Data,' American Economic Journal: Macroeconomics, 5(2), 217-249.

Baker, Scott, Nick Bloom, Brandice Canes-Wrone, Steven Davis, and Jonathan Rodden (2015), 'Why Has U.S. Policy Uncertainty Risen Since 1960?' www.policyuncertainty.com/media/BBCDR_Uncertainty.pdf.

Baker, Scott, Nick Bloom, and Steven Davis (2013), 'Measuring Economic Policy Uncertainty,' www.policyuncertainty.com/media/BakerBloomDavis.pdf.

Baker, Scott, Nick Bloom, and Steven Davis (2015), 'What Triggers Stock Market Jumps?' Presentation at ASSA Meetings, Boston, www.policyuncertainty.com/media/BBD_StockJumps.pdf.

Bansel, Ravi and Amir Yaron (2004), 'Risks for the Long Run: A Potential Resolution of Asset Pricing Puzzles,' Journal of Finance, 59(4), 1481-1509.

Bartel, Ann, Casey Ichniowski, and Kathryn Shaw (2007), 'How Does Information Technology Affect Productivity? Plant-Level Comparisons of Product Innovation, Process Improvement, and Worker Skills,' Quarterly Journal of Economics, 122(4), 1721-1758.

Ben-David, Itzhak, John R. Graham, and Campbell R. Harvey (2013), 'Managerial Miscalibration,' Quarterly Journal of Economics, 128(4), 1547-1584. 
Bertrand, Marianne and Antoinette Schoar (2003), 'Managing with Style: The Effect of Managers on Firm Policies,' Quarterly Journal of Economics, 118(4), 1169-1208.

Black, Sandra and Lisa Lynch (2001), 'How to Compete: The Impact of Workplace Practices and Information Technology on Productivity,' Review of Economics and Statistics, 83(3), 434-445.

Bloom, Nicholas (2009), ‘The Impact of Uncertainty Shocks,' Econometrica 77(3), 623-685.

Bloom, Nicholas (2014), 'Fluctuations in Uncertainty,' Journal of Economic Perspectives, 28(2), 153-176.

Bloom, Nicholas, Steve Bond, and John Van Reenen (2007), 'Uncertainty and Investment Dynamics,' Review of Economic Studies, 74(2), 391-415.

Bloom, Nicholas, Erik Brynjolfsson, Lucia Foster, Ron Jarmin, Megha Patnaik, Itay SaportaEksten, and John Van Reenen (2014), 'IT and Management in America,' CEP Discussion Paper 1258.

Bloom, Nicholas, Erik Brynjolfsson, Lucia Foster, Ron Jarmin, Megha Patnaik, Itay SaportaEksten, and John Van Reenen (2016), 'What Drives Differences in Management?' Stanford mimeo.

Bloom, Nicholas, Erik Brynjolfsson, Lucia Foster, Ron Jarmin, Itay Saporta-Eksten, and John Van Reenen (2013), 'Management in America,' CES Working Paper 13-01.

Bloom, Nicholas, Benn Eifert, Aprajit Mahajan, David McKenzie, and John Roberts (2013), 'Does Management Matter? Evidence from India,' Quarterly Journal of Economics, 128(1), $1-51$.

Bloom, Nicholas, Luis Garicano, Raffaella Sadun, and John Van Reenen (2009), 'The Distinct Effects of Information Technology and Communication Technology on Firm Organization,' NBER Working Paper 14975.

Bloom, Nicholas, Renata Lemos, Raffaella Sadun, Daniela Scur, and John Van Reenen (2014), 'The New Empirical Economics of Management,' Journal of the European Economic Association, 12(4), 835-876.

Bloom, Nicholas, Renata Lemos, Raffaella Sadun, Daniela Scur, and John Van Reenen (2016), 'International Data on Measuring Management Practices,' CEP Occasional Paper 46.

Bloom, Nicholas, Renata Lemos, Raffaella Sadun, and John Van Reenen (2014), 'Does Management Matter in Schools?' LSE mimeo. 
Bloom, Nicholas, Raffaella Sadun, and John Van Reenen (2012a), 'Americans Do IT Better,' American Economic Review, 102(1), 167-201.

Bloom, Nicholas, Raffaella Sadun, and John Van Reenen (2012b), 'The Organization of Firms across Countries,' Quarterly Journal of Economics, 127(4), 1663-1705.

Bloom, Nicholas, Raffaella Sadun, and John Van Reenen (2013), 'Does Management Matter in Healthcare?' LSE mimeo.

Bloom, Nicholas, Raffaella Sadun, and John Van Reenen (2015a), 'Management as a Technology?' LSE mimeo.

Bloom, Nicholas, Raffaella Sadun, and John Van Reenen (2015b), 'Do Private Equity Owned Firms Have Better Management Practices?’ American Economic Review, 105(5), 442-46.

Bloom, Nicholas, Helena Schweiger, and John Van Reenen (2012), 'The Land that Lean Manufacturing Forgot? Management Practices in Transition Countries,' Economics of Transition, 20(4), 593-635.

Bloom, Nicholas and John Van Reenen (2007), 'Measuring and Explaining Management Practices across Firms and Countries,' Quarterly Journal of Economics, 122(4), 1351-1408.

Bresnahan, Timothy F., Erik Brynjolfsson, and Lorin M. Hitt (2002), 'Information Technology, Workplace Organization, and the Demand for Skilled Labor: Firm-Level Evidence,' Quarterly Journal of Economics, 117(1), 339-376.

Brouillette, Dany and Daniel Ershov (2014), 'Management Practices, Competition, Innovation, and the Performance of Enterprises in Canada,' Industry Canada Economic Research and Policy Analysis Branch Working Paper 2014-02.

Brynjolfsson, Erik and Lorin M. Hitt (1997), 'Information Technology and Organizational Design: Evidence from Firm-level Data,’ MIT Sloan School Working Paper.

Brynjolfsson, Erik, Lorin M. Hitt, and Heekyung Hellen Kim (2011), 'Strength in Numbers: How Does Data-Driven Decisionmaking Affect Firm Performance?’ SSRN Working Paper 1819486.

Brynjolfsson, Erik, and Kristina McElheran (2016), 'Data in Action: Data-Driven Decision Making in U.S. Manufacturing,’ CES Working Paper 16-06.

Brynjolfsson, Erik, and Haim Mendelson (1993), 'Information Systems and the Organization of Modern Enterprise,' Journal of Organizational Computing, 3(3), 245-255.

Cappelli, Peter (2002), 'The National Employer Survey: Employer Data on Employment Practices,' Industrial Relations, 40(4), 635-647. 
Cappelli, Peter and David Neumark (2001), 'Do 'High-Performance' Work Practices Improve Establishment-Level Outcomes?’ Industrial and Labor Relations Review, 54(4), 737-775.

D’Aurizio, Leandro and S. Iezzi (2010), 'Investment Forecasting with Plans Collected in Business Surveys,’ Bank of Italy Temi di Discussione No. 832.

De Mel, Suresh, David McKenzie, and Christopher Woodruff (2014) "Business Training and Female Enterprise Start-up, Growth, and Dynamics: Experimental Evidence from Sri Lanka”, Journal of Development Economics, 106, 199-210.

Delfgaauw, Josse, Robert Dur, Carol Propper, and Sarah Smith (2011), 'Management Practices: Are Not for Profits Different?' CMPO working paper 11/263.

Dohrmann, Thomas and Gary Pinshaw (2009), The Road to Improved Compliance: A McKinsey Benchmarking Study of Tax Administrations, 2008-2009. New York: McKinsey and Company.

Foster, Lucia, John Haltiwanger, and Chad Syverson (2008), 'Reallocation, Firm Turnover, and Efficiency: Selection on Productivity or Profitability?’ American Economic Review, 98(1), 394-425.

Gibbons, Robert and Rebecca Henderson (2013), 'What Do Managers Do? Exploring Persistent Performance Differences Among Seemingly Similar Enterprises,' in The Handbook of Organizational Economics, Robert Gibbons and John Roberts (eds.), Princeton University Press: Princeton, NJ, 680-731.

Haltom, Renee and Nick Bloom (2014), 'Interview: Nicholas Bloom,' Econ Focus, Federal Reserve Bank of Richmond, https://www.richmondfed.org/publications/research/econ_focus/2014/q2/interview.cfm.

Homkes, Rebecca (2011), 'The Missing Management Link: Why Management Matters in Global Public-Private Partnerships,’ LSE mimeo.

Hong, Bryan, Lorenz Kueng, and Mu-Jeung Yang (2015), 'Estimating Management Practice Complementarity between Decentralization and Performance Pay,’ NBER Working Paper 20845.

Horvath, Francis W. (1982), 'Forgotten Unemployment: Recall Bias in Retrospective Data,' Monthly Labor Review, 105(3), 40-43.

Hsieh, Chang-Tai and Peter Klenow (2009), 'Misallocation and Manufacturing TFP in China and India,' Quarterly Journal of Economics, 124(4), 1403-1448.

Ichniowski, Casey, Kathryn Shaw, and Giovanna Prennushi (1997), 'The Effects of Human Resource Management: A Study of Steel Finishing Lines,' American Economic Review, 87(3), 291-313. 
Jurado, Kyle, Sydney C. Ludvigson, and Serena Ng (2015), 'Measuring Uncertainty,' American Economic Review, 105(3), 1177-1216.

Karlan, Dean, Ryan Knight, and Christopher Udry (2012), 'Hoping to Win, Expected to Lose, Theory and Lessons on Micro Enterprise Development,’ NBER Working Paper 18325.

Knight, Frank H. (1921), Risk, Uncertainty, and Profit, Houghton Mifflin Company: New York, NY.

Marris, Robin (1964), The Economic Theory of 'Managerial' Capitalism, Macmillan: New York, NY.

McConnell, K. John, Kim Hoffman, Andrew Quanbeck, and Dennis McCarty (2009), 'Management Practices in Substance Abuse Treatment Programs' Journal of Substance Abuse, 37(1), 79-89.

McConnell, K. John, Richard C. Lindrooth, Douglas R. Wholey, Thomas M. Maddox, and Nick Bloom (2013), 'Management Practices and the Quality of Care in Cardiac Units,' JAMA Internal Medicine, 173(8), 684-692.

McConnell, K. John, Richard C. Lindrooth, Douglas R. Wholey, Thomas M. Maddox, and Nick Bloom (2016), 'Modern Management Practices and Hospital Admissions,' Health Economics, 25(4), 470-485.

McCormack, John, Carol Propper, and Sarah Smith (2013), 'Herding cats? Management and University Performance,' Economic Journal, 124(578), F534-F564.

McElheran, Kristina (2014), 'Delegation in Multi-Establishment Firms: Evidence from IT Purchasing,' Journal of Economics and Management Strategy, 23(2), 225-258.

McKenzie, David and Christopher Woodruff (2012), 'What are We Learning from Business Training and Entrepreneurship Evaluations around the Developing World?' IZA Discussion Paper 6895.

McKinsey and Company (2009), 'Management Matters in Northern Ireland and the Republic of Ireland,' http://www.delni.gov.uk/managementmatters.

Milgrom, Paul and John Roberts (1990), 'The Economics of Modern Manufacturing: Technology, Strategy, and Organization,' American Economic Review, 80(3), 511-528.

Radner, Roy (1992), 'Hierarchy: The Economics of Managing,' Journal of Economic Literature, 30(3), 1382-1415.

Rahaman, Mohammad M. and Ashraf Al Zaman (2013), 'Management Quality and the Cost of Debt: Does Management Matter to Lenders?' Journal of Banking and Finance, 37(3), 854874. 
Rasul, Imran and Daniel Rogger (2013), 'Management of Bureaucrats and Public Service Delivery,' UCL mimeo.

Rasul, Imran and Daniel Rogger (2015), 'The Impact of Ethnic Diversity in Bureaucracies: Evidence from the Nigerian Civil Service,' American Economic Review, 105(5): 457-61.

Roberts, John and Garth Saloner (2013), 'Strategy and Organization,' in The Handbook of Organizational Economics, Robert Gibbons and John Roberts (eds.), Princeton University Press: Princeton, NJ, 799-849.

Syverson, Chad (2004), 'Product Substitutability and Productivity Dispersion,' Review of Economics and Statistics, 86(2), 534-550.

Syverson, Chad (2011), 'What Determines Productivity?’ Journal of Economic Literature, 49(2), 326-365.

Walker, Francis (1887), 'The Source of Business Profits,' Quarterly Journal of Economics, 1(3): 265-288.

Yang, Mu-Jeung, Lorenz Kueng, and Bryan Hong (2015), 'Business Strategy and the Management of Firms,’ NBER Working Paper 20846. 
Table 1: Management Surveys in the U.S.

\begin{tabular}{|c|c|c|c|c|}
\hline Name of Survey & Conducted by & $\begin{array}{c}\text { Unit of } \\
\text { Observation }\end{array}$ & Number of Units & Industry \\
\hline $\begin{array}{l}\text { Computer Intelligence } \\
\text { Database }\end{array}$ & Harte Hanks & "Establishment & 116,000 & "Representative \\
\hline $\begin{array}{l}\text { Management and } \\
\text { Organizational Practices } \\
\text { Survey (MOPS 2010) } \\
\end{array}$ & U.S. Census Bureau & Establishment & 37,177 & Manufacturing \\
\hline $\begin{array}{l}\text { National Employer Survey } \\
\text { (NES) }\end{array}$ & U.S. Census Bureau & Establishment & 3100 & $\begin{array}{l}\text { All establishments with } 20 \text { or more } \\
\text { employees, excluding agriculture and } \\
\text { government }\end{array}$ \\
\hline $\begin{array}{l}\text { World Management Survey } \\
\text { (WMS) }\end{array}$ & World Management Survey & Firm $^{1}$ & 1487 & Manufacturing \\
\hline WMS & World Management Survey & School & 279 & Education \\
\hline Self-Administered Survey & $\begin{array}{l}\text { Bartel, Ichniowski, and } \\
\text { Shaw (2013) }\end{array}$ & Establishment & 212 & $\begin{array}{l}\text { Valve-making plants with more than } \\
20 \text { employees }\end{array}$ \\
\hline Self-Administered Survey & Bertrand and Schoar (2003) & Firm/manager & Approximately 600 firms and 500 managers & $\begin{array}{l}\text { Largest publicly-traded firms } \\
\text { excluding banking, insurance, } \\
\text { utilities. }\end{array}$ \\
\hline Self-Administered Survey & $\begin{array}{l}\text { Ichniowski, Shaw, and } \\
\text { Prennushi (1997) }\end{array}$ & Production Line & 36 & Steel \\
\hline Self-Administered Survey & $\begin{array}{l}\text { McConnell, Hoffman, } \\
\text { Quanbeck, and McCarty } \\
\text { (2009) }\end{array}$ & Firm & 172 & Addiction Treatment \\
\hline Self-Administered Survey & $\begin{array}{l}\text { McConnell, Lindrooth, } \\
\text { Wholey, Maddox, and } \\
\text { Bloom (2013) }\end{array}$ & Cardiac unit & 597 & Healthcare \\
\hline
\end{tabular}

\footnotetext{
${ }^{1}$ Although the WMS is conducted at the establishment level, analysis can only be conducted at the firm level due to the reliance on public data for performance. This note applies to other surveys that incorporate the WMS methodology, including the MOI survey.
} 
Table 2: Management Surveys around the World

\begin{tabular}{|c|c|c|c|c|c|}
\hline Name of Survey & Conducted by & $\begin{array}{c}\text { Unit of } \\
\text { Observation }\end{array}$ & Number of Units & Industry & Country \\
\hline $\begin{array}{l}\text { Changements Organisationnels } \\
\text { et Informatisation (COI) }\end{array}$ & "SESSI & Firm & 4153 & Manufacturing & France \\
\hline Enquête Response (ER) & DARES & Establishment & 2943 & $\begin{array}{l}\text { Manufacturing and } \\
\text { non-manufacturing }\end{array}$ & France \\
\hline $\begin{array}{l}\text { Management, Organisation, and } \\
\text { Innovation Survey (MOI) }\end{array}$ & $\begin{array}{l}\text { European Bank for Reconstruction and } \\
\text { Development, World Bank }\end{array}$ & Firm & 1874 & Manufacturing & $\begin{array}{l}10 \text { transition } \\
\text { countries, } \\
\text { Germany, } \\
\text { India }\end{array}$ \\
\hline $\begin{array}{l}\text { Survey of Innovation and } \\
\text { Business Strategy (SIBS) }\end{array}$ & Statistics Canada & Establishment & Between 4000 and 8000 & 14 Industries & Canada \\
\hline $\begin{array}{l}\text { Workplace and Employee } \\
\text { Survey (WES) }\end{array}$ & Statistics Canada & $\begin{array}{l}\text { Establishment/ } \\
\text { worker }\end{array}$ & $\begin{array}{r}\text { Approximately } 10,000-15,000 \\
\text { establishments and } 20,000 \\
\text { workers (varies by year) }\end{array}$ & Representative & Canada \\
\hline $\begin{array}{l}\text { Workplace Employee Relations } \\
\text { Survey (WERS) }\end{array}$ & $\begin{array}{l}\text { Department for Business, Innovation and } \\
\text { Skills }\end{array}$ & $\begin{array}{l}\text { Establishment/ } \\
\text { worker }\end{array}$ & $\begin{array}{r}\text { Approximately 2500 } \\
\text { workplaces and 23,000 } \\
\text { workers (varies by year) }\end{array}$ & Representative & UK \\
\hline $\begin{array}{l}\text { World Management Survey } \\
\text { (WMS) }\end{array}$ & World Management Survey & Firm & 13,285 & Manufacturing & 33 countries \\
\hline WMS & Centre for Economic Performance (LSE) & Firm & 100 & Healthcare & England \\
\hline WMS & World Management Survey & Firm & 1672 & Education & 7 countries \\
\hline Self-Administered Survey & $\begin{array}{l}\text { Bloom, Eifert, Mahajan, McKenzie, and } \\
\text { Roberts (2013) }\end{array}$ & Establishment & 17 & Textiles & India \\
\hline Self-Administered Survey & $\begin{array}{l}\text { Delfgaauw, Dur, Propper, and Smith } \\
\text { (2013) }\end{array}$ & Firm & 200 & $\begin{array}{l}\text { Fostering, adoption, } \\
\text { and nursing }\end{array}$ & UK \\
\hline Self-Administered Survey & McCormack, Propper, and Smith (2013) & Department & 248 & University & UK \\
\hline Self-Administered Survey & McKinsey \& Co. ${ }^{1}$ & Agency & 13 & Tax Administration & 13 countries \\
\hline Self-Administered Survey & McKinsey \& Co. & Firm & 270 & Manufacturing & $\begin{array}{l}\text { Ireland, } \\
\text { Northern } \\
\text { Ireland }\end{array}$ \\
\hline Self-Administered Survey & Rasul and Rogger (2013) & Agency & 63 & Civil Service & Nigeria \\
\hline
\end{tabular}

\footnotetext{
${ }^{1}$ Findings summarized in Dohrmann and Pinshaw (2009).
} 


\section{Appendix A: MOPS 2010 Instrument}

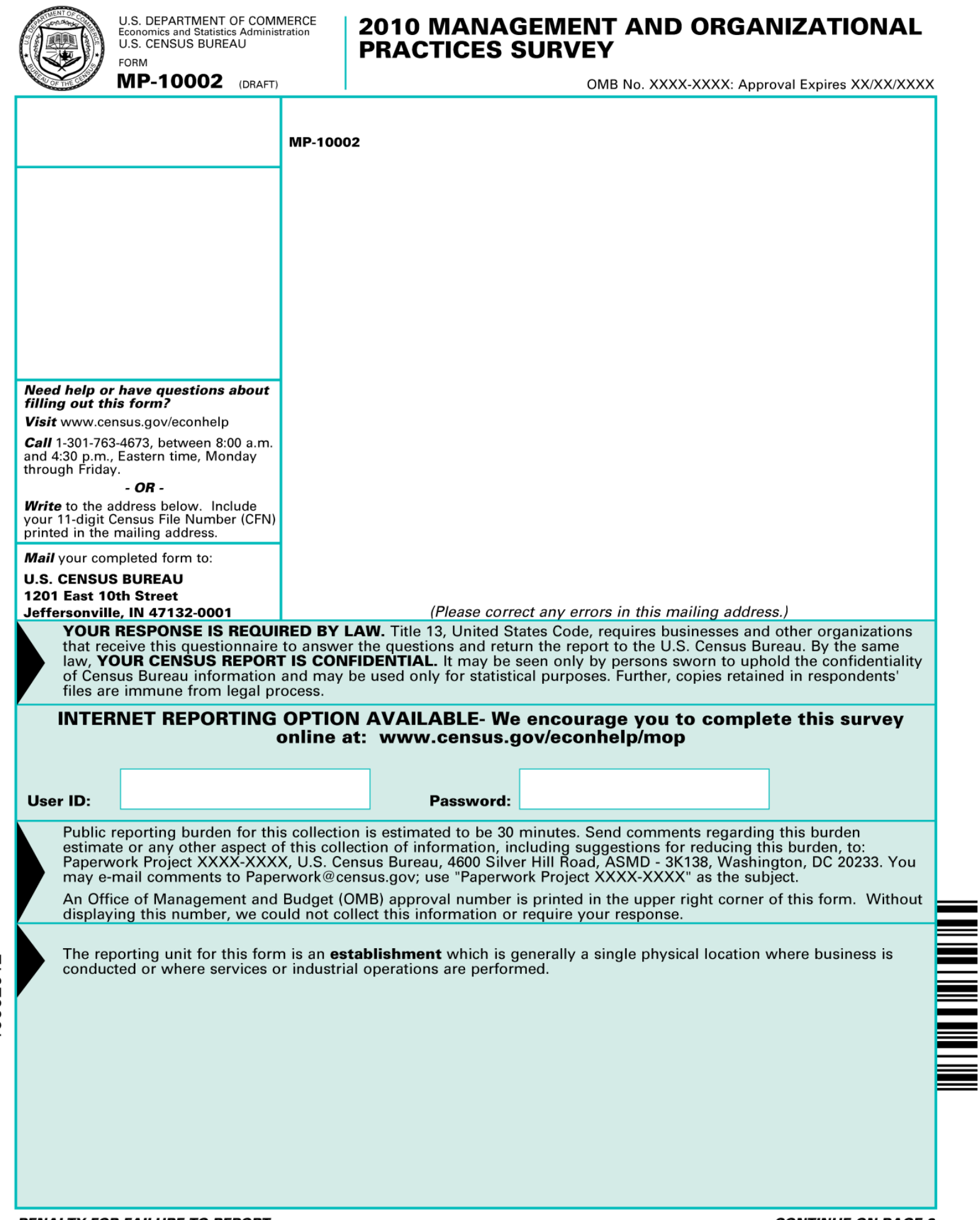




\section{Section A - Management Practices}

1 In 2005 and 2010, what best describes what happened at this establishment when a problem in the production process arose?

Examples: Finding a quality defect in a product or a piece of machinery breaking down.

Check one box for each year

\begin{tabular}{|l|r|}
\hline 2005 & 2010 \\
\hline
\end{tabular}

We fixed it but did not take further action

We fixed it and took action to make sure that it did not happen again

We fixed it and took action to make sure that it did not happen again, and had a continuous improvement process to anticipate problems like these in advance

No action was taken

2 In 2005 and 2010, how many key performance indicators were monitored at this establishment?

Examples: Metrics on production, cost, waste, quality, inventory, energy, absenteeism and deliveries on time.

Check one box for each year

\begin{tabular}{|l|r|}
\hline 2005 & 2010 \\
\hline
\end{tabular}

1-2 key performance indicators

3-9 key performance indicators

10 or more key performance indicators

No key performance indicators (If no key performance indicators in both years, SKIP to

()

3 During 2005 and 2010, how frequently were the key performance indicators reviewed by managers at this establishment? Mark all that apply

A manager is someone who has employees directly reporting to them, with whom they meet on a regular basis, and whose pay and promotion they may be involved with, e.g., Plant Manager, Human Resource Manager, Quality Manager.

\begin{tabular}{r|r|r|}
\cline { 2 - 3 } 2005 & 2010 \\
\hline
\end{tabular}

Yearly

Quarterly

Monthly

Weekly

Daily

Hourly or more frequently

Never

\begin{tabular}{l|l}
$\square$ & $\square$ \\
$\square$ & $\square$ \\
$\square$ & $\square$ \\
$\square$ & $\square$ \\
$\square$ & $\square$ \\
$\square$ & $\square$ \\
$\square$ & $\square$
\end{tabular}

ํㅗㅇ
응

CONTINUE ON PAGE 3 
If not shown, please enter your 11-digit Census File

Number (CFN) from the mailing address.

4 During 2005 and 2010, how frequently were the key performance indicators reviewed by non-managers at this establishment? Mark all that apply

Non-managers are all employees at the establishment who are not managers as defined in 3

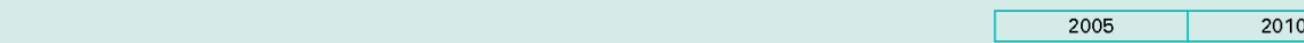

Yearly

Quarterly

Monthly

Weekly

Daily

Hourly or more frequently

Never

(1)

5 During 2005 and 2010, where were the production display boards showing output and other key performance indicators located at this establishment? Check one box for each year

All display boards were located in one place (e.g. at the end of the production line)

\begin{tabular}{c|c|c}
\hline & 2005 & 2010 \\
\hline & $\square$ & $\square$ \\
0 & $\square$ & $\square$ \\
& $\square$ & $\square$
\end{tabular}

We did not have any display boards

6 In 2005 and 2010, what best describes the time frame of production targets at this establishment? Check one box for each year

Examples of production targets are: production, quality, efficiency, waste, on-time delivery.

\section{Examples of production targets are: production, quality, efficiency, waste, on-time delivery.}

Main focus was on short-term (less than one year) production targets

Main focus was on long-term (more than one year) production targets

Combination of short term and long term production targets

No production targets (If no production targets in both years, SKIP to (13)

7 In 2005 and 2010, how easy or difficult was it for this establishment to achieve its production targets?

Check one box for each year

\begin{tabular}{|l|l}
\hline 2005 & 2010 \\
\hline
\end{tabular}

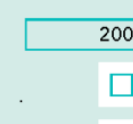

Possible to achieve with some effort

Possible to achieve with normal amount of effort

Possible to achieve with more than normal effort

Only possible to achieve with extraordinary effort

CONTINUE ON PAGE 4 
In 2005 and 2010, who was aware of the production targets at this establishment? Check one box for each year

Only senior managers

Most managers and some production workers

Most managers and most production workers

All managers and most production workers

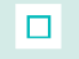

口

In 2005 and 2010, what were non-managers' performance bonuses usually based on? Mark all that apply

Their own performance as measured by production targets

Their team or shift performance as measured by production targets

Their establishment's performance as measured by production targets

Their company's performance as measured by production targets

No performance bonuses (If no performance bonuses in both years, SKIP to (11)

10 In 2005 and 2010, when production targets were met, what percent of non-managers at this establishment received performance bonuses? Check one box for each year

$0 \%$

$1-33 \%$

$34-66 \%$

$67-99 \%$

$100 \%$

Production targets not met

\begin{tabular}{|l|r|}
\hline 2005 & 2010 \\
\hline
\end{tabular}

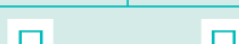

In 2005 and 2010, what were managers' performance bonuses usually based on? Mark all that apply

(11)

Their own performance as measured by production targets

Their team or shift performance as measured by production targets

Their establishment's performance as measured by production targets

Their company's performance as measured by production targets

No performance bonuses (If no performance bonuses in both years, SKIP to (13) 
If not shown, please enter your 11-digit Census File

Number (CFN) from the mailing address.

12 In 2005 and 2010, when production targets were met, what percentage of managers at this establishment received performance bonuses? Check one box for each year

$0 \%$

\begin{tabular}{|l|r|}
\hline 2005 & 2010 \\
\hline
\end{tabular}

$1-33 \%$

$34-66 \%$

$67-99 \%$

$100 \%$

Production targets not met

13 In 2005 and 2010, what was the primary way non-managers were promoted at this establishment?

Check one box for each year

\begin{tabular}{|l|l|}
\hline 2005 & 2010 \\
\hline
\end{tabular}

Promotions were based solely on performance and ability

Promotions were based partly on performance and ability, and partly on other factors (for example, tenure or family connections)

Promotions were based mainly on factors other than performance and ability (for

example, tenure or family connections)

Non-managers are normally not promoted

14 In 2005 and 2010, what was the primary way managers were promoted at this establishment?

Check one box for each year

\begin{tabular}{r|r}
\hline 2005 & 2010 \\
\hline & $\square$ \\
\hline & $\square$ \\
$\square$ & $\square$ \\
$\square$ & $\square$ \\
$\square$ & $\square$
\end{tabular}

15

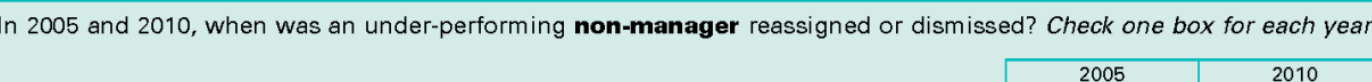

Promotions were based solely on performance and ability

Promotions were based partly on performance and ability, and partly on other factors (for example, tenure or family connections)

Promotions were based mainly on factors other than performance and ability (for example, tenure or family connections)

Managers are normally not promoted

Within 6 months of identifying non-manager under-performance

After 6 months of identifying non-manager under-performance

융

Rarely or never

$\square$

$\square$

$\square$

$\square$

CONTINUE ON PAGE 6 
Form MP-10002 (DRAFT)

10 In 2005 and 2010, when was an under-performing manager reassigned or dismissed? Check one box for each year

Within 6 months of identifying manager under-performance

\begin{tabular}{|l|l|}
\hline 2005 & 2010 \\
\hline
\end{tabular}

After 6 months of identifying manager under-performance

Rarely or never

\section{Section B - Organization}

17 In 2005 and 2010, was the headquarters for this company at the same location as this establishment? Check one box for each year

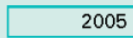

Yes (If yes in both years, SKIP to 24)

No

18 In 2005 and 2010, where were decisions on hiring permanent full-time employees made?

Check one box for each year

2005

Only at this establishment

Only at headquarters

Both at this establishment and at headquarters

Other (please specify)

19 In 2005 and 2010, where were decisions to give an employee a pay increase of at least $10 \%$ made?

Check one box for each year

\begin{tabular}{|l|r|}
\hline 2005 & 2010 \\
\hline
\end{tabular}

Only at this establishment

Only at headquarters

Both at this establishment and at headquarters

Other (please specify)

20 In 2005 and 2010, where were decisions on new product introductions made? Check one box for each year

\begin{tabular}{r|r|r|}
\cline { 2 - 3 } & 2005 \\
\hline
\end{tabular}

Only at this establishment

Only at headquarters

Both at this establishment and at headquarters

Other (please specify) 
If not shown, please enter your 11-digit Census File

Number (CFN) from the mailing address.

21 In 2005 and 2010, where were product pricing decisions made? Check one box for each year

\begin{tabular}{|r|r|} 
& 2005 \\
\hline
\end{tabular}

Only at this establishment

Only at headquarters

Both at this establishment and at headquarters

Other (please specify)

$\square$

In 2005 and 2010, where were advertising decisions for products made? Check one box for each year

Only at this establishment

Only at headquarters

Both at this establishment and at headquarters

Other (please specify)

23 In 2005 and 2010, what was the dollar amount that could be used to purchase a fixed/capital asset at this establishment without prior authorization from headquarters? Check one box for each year

\begin{tabular}{|l|l|}
\hline 2005 & 2010 \\
\hline
\end{tabular}

$\square$

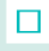

\begin{tabular}{|l|l|}
\hline 2005 & 2010 \\
\hline
\end{tabular}

Under $\$ 1,000$

$\$ 1,000$ to $\$ 9,999$

$\$ 10,000$ to $\$ 99,999$

$\$ 100,000$ to $\$ 999,999$

$\$ 1$ million or more

24 In 2005 and 2010, what was the number of employees reporting directly to the plant manager at this establishment?

A plant manager's direct report is someone in the organizational level directly below them, with whom they meet on a regular basis, and whose pay and promotion they may be involved with.

Number of direct reports (Estimates are acceptable)

\begin{tabular}{|l|l|}
\hline 2005 & 2010 \\
\hline & \\
\hline
\end{tabular}

25 In 2005 and 2010, how many layers of direct reports were there in this establishment from the factory floor to the plant manager, inclusive?

Example: For a site with a factory floor, factory supervisors and a plant manager, the number of layers would be 3 .

Number of layers (Estimates are acceptable)

\begin{tabular}{|l|l|}
\hline 2005 & 2010 \\
\hline & \\
& \\
\hline
\end{tabular}

CONTINUE ON PAGE 8 
Form MP-10002 (DRAFT)

20 In 2005 and 2010, who prioritized or allocated tasks to production workers at this establishment?

Check one box for each year

Only managers

Mostly managers

Managers and production workers jointly

Mostly production workers

Only production workers

Other (please specify)

27 In 2005 and 2010, what best describes the availability of data to support decision making in this establishment?

Check one box for each year

\begin{tabular}{|l|r|}
\hline 2005 & 2010 \\
\hline
\end{tabular}

Data to support decision making are not available

A small amount of data to support decision making is available

A moderate amount of data to support decision making is available

A great deal of data to support decision making is available

All the data we need to support decision making is available

28 In 2005 and 2010, what best describes the use of data to support decision making in this establishment?

Check one box for each year

\begin{tabular}{|l|r|}
\hline 2005 & 2010 \\
\hline
\end{tabular}

Decision making does not use data

Decision making relies slightly on data

Decision making relies moderately on data

Decision making relies heavily on data

Decision making relies entirely on data

29 In 2005 and 2010, did the managers at this establishment learn about management practices from any of the following?

Mark all that apply

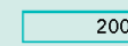

Consultants

Competitors

Suppliers

Customers

Trade associations or conferences

New employees

Headquarters

Other (please specify)

None of the above

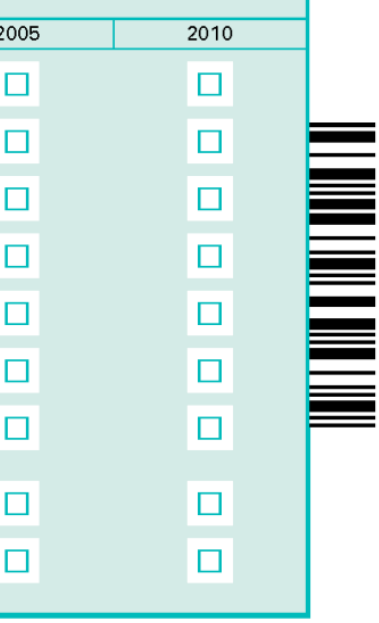

CONTINUE ON PAGE 9 
Form MP-10002 (DRAFT)

If not shown, please enter your 11-digit Census File

Number (CFN) from the mailing address.

Section C - Background Characteristics

30 What was your level of seniority in 2010 ?

$\square$ CEO or Executive Officer, e.g., CFO

$\square$ Manager of multiple establishments, e.g., Division Manager

$\square$ Manager of one establishment, e.g., Plant Manager or Controller

Non-manager

Other (please specify)

31 What year did you start working at this establishment?

32 What was the number of managers at this establishment for the pay periods including March 12, 2005 and March 12 , 2010 ?

A manager is someone who has employees directly reporting to them, with whom they meet on a regular basis, and whose pay and promotion they may be involved with, e.g., Plant Manager, Human Resource Manager, Quality Manager.

Number of managers at this establishment (Estimates are acceptable)

\begin{tabular}{|c|c|}
\hline 2005 & 2010 \\
\hline & \\
\hline
\end{tabular}

33 What was the number of all full and part-time employees at this establishment for the pay periods including March 12 , 2005 and March 12, 2010?

Number of employees at this establishment (Estimates are acceptable)

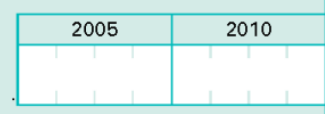

34 In 2005 and 2010, what was the percent of managers at this establishment with a bachelors degree?

Check one box for each year

\begin{tabular}{|l|r|}
\hline 2005 & 2010 \\
\hline
\end{tabular}

$20 \%$ or less

$21 \%-40 \%$

$41 \%-60 \%$

$61 \%-80 \%$

More than $80 \%$

35 In 2005 and 2010, what was the percent of non-managers at this establishment with a bachelors degree?

$0 \%$

$1-10 \%$

$11-20 \%$

More than $20 \%$

\begin{tabular}{|c|c|}
\hline 2005 & 2010 \\
\hline$\square$ & $\square$ \\
\hline Б & $\square$ \\
\hline [ & $\square$ \\
\hline ए & $\square$ \\
\hline
\end{tabular}

CONTINUE ON PAGE 10 
30 In 2005 and 2010, what percent of all employees at this establishment were members of a labor union?

Check one box for each year

\begin{tabular}{|l|l|}
\hline 2005 & 2010 \\
\hline
\end{tabular}

$0 \%$

$1-20 \%$

$21-40 \%$

$41-60 \%$

$61-80 \%$

More than $80 \%$

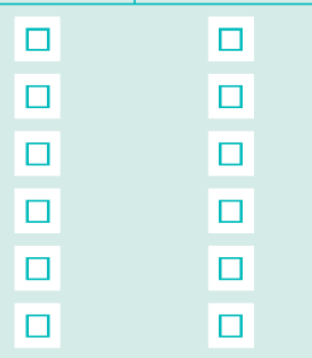

REMARKS (Please use this space for any explanations that may be essential in understanding your reported data.)

37 CERTIFICATION - This report is substantially accurate and was prepared in accordance with the instructions. Is the time period covered by this report a calendar year?

$\square$ Yes

No - Enter time period covered

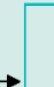

FROM

\begin{tabular}{|l|l} 
Month & Year \\
\hline &
\end{tabular}

TO

\begin{tabular}{|c|c|c|c|c|c|c|c|c|}
\hline \multicolumn{4}{|c|}{ Name of person to contact regarding this report } & \multicolumn{5}{|l|}{ Title } \\
\hline Telephone & Area code & Extension & Extension & Fax & Area code & \multicolumn{3}{|c|}{ Number } \\
\hline \multicolumn{4}{|c|}{ Internet e-mail address } & \multicolumn{2}{|c|}{$\begin{array}{l}\text { Date } \\
\text { completed }\end{array}$} & Month & Day & Year \\
\hline
\end{tabular}

응

\section{Thank you for completing your 2010 MANAGEMENT AND ORGANIZATIONAL} PRACTICES form.

PLEASE PHOTOCOPY THIS FORM FOR YOUR RECORDS AND RETURN THE ORIGINAL. 


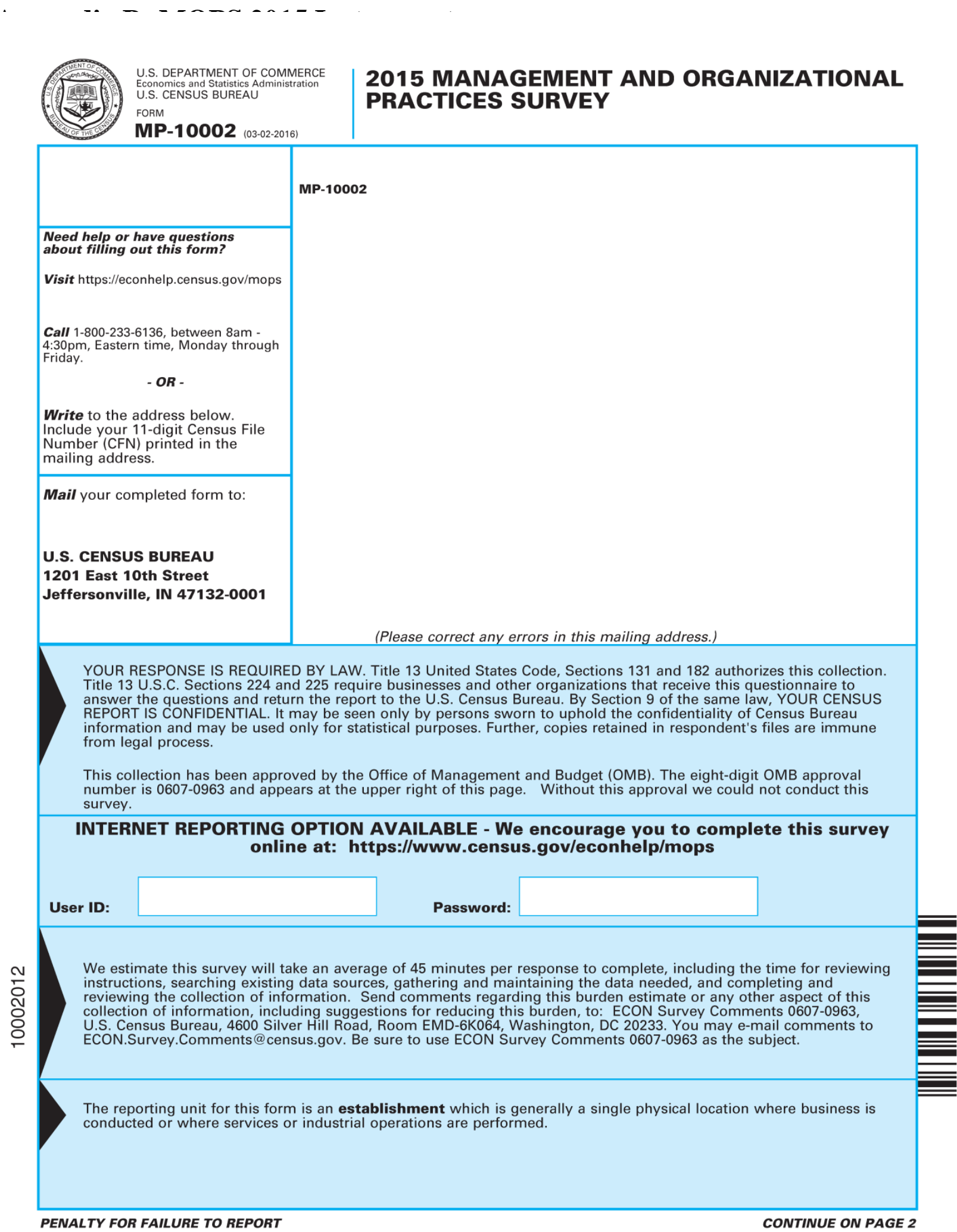

PENALTY FOR FAILURE TO REPORT

CONTINUE ON PAGE 2 
Section A - Management Practices

1 In 2010 and 2015, what best describes what happened at this establishment when a problem in the production process arose?

Examples: Finding a quality defect in a product or a piece of machinery breaking down.

\section{Mark one box for each year}

\begin{tabular}{|l|r|}
\hline 2010 & 2015 \\
\hline
\end{tabular}

We fixed it but did not take further action

We fixed it and took action to make sure that it did not happen again

We fixed it and took action to make sure that it did not happen again, and had a continuous improvement process to anticipate problems like these in advance

No action was taken

2 In 2010 and 2015 , how many key performance indicators were monitored at this establishment?

Examples: Metrics on production, cost, waste, quality, inventory, energy, absenteeism and deliveries on time.

\section{Mark one box for each year}

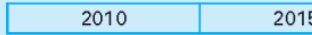

1-2 key performance indicators

3-9 key performance indicators

10 or more key performance indicators

No key performance indicators

(If no key performance indicators in both years, SKIP to 6)

3 During 2010 and 2015, how frequently were the key performance indicators reviewed by managers at this establishment?

\section{Mark all that apply}

A manager is someone who has employees directly reporting to them, with whom they meet on a regular basis, and whose pay and promotion they may be involved with, e.g., Plant Manager, Human Resource Manager, Quality Manager

Yearly

Quarterly

Monthly

Weekly

Daily

Hourly or more frequently

Never

\begin{tabular}{|l|l|}
\hline 2010 & 2015 \\
\hline
\end{tabular}

$\square$

$\square$

ํㅣㅇ
응 
If not shown, please enter your 11-digit Census File

Number (CFN) from the mailing address.

4 During 2010 and 2015, how frequently were the key performance indicators reviewed by non-managers at this establishment?

\section{Mark all that apply}

Non-managers are all employees at the establishment who are not managers as defined in 3

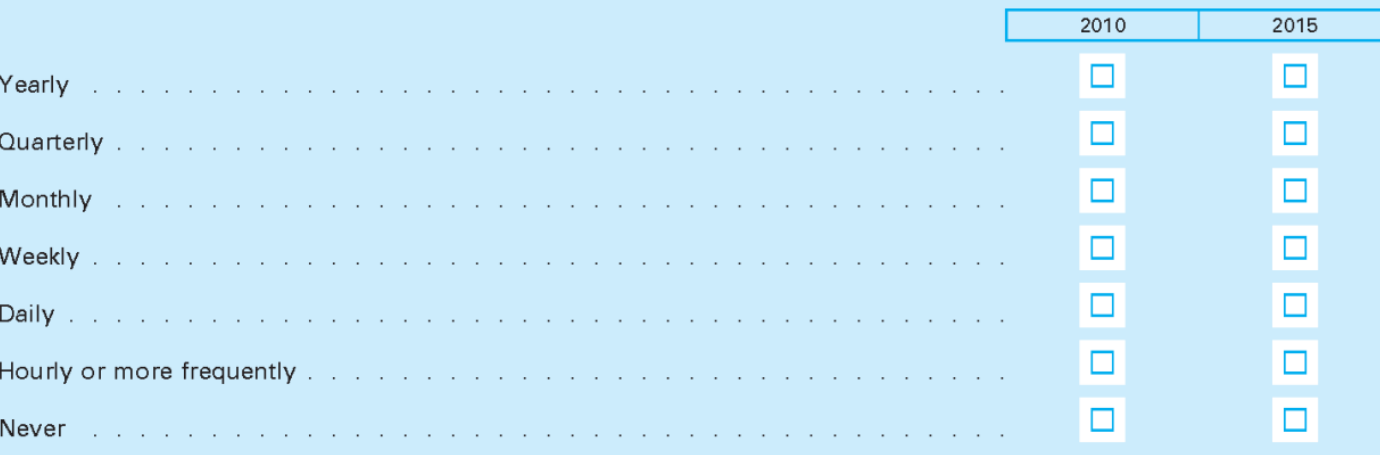

5 During 2010 and 2015 , where were the production display boards showing output and other key performance indicators located at this establishment?

\section{Mark one box for each year}

\begin{tabular}{|c|c|}
\hline 2010 & 2015 \\
\hline$\square$ & $\square$ \\
\hline$\square$ & $\square$ \\
\hline$\square$ & $\square$ \\
\hline
\end{tabular}

All display boards were located in one place (e.g. at the end of the production line) Display boards were located in multiple places (e.g. at multiple stages of the production line)

We did not have any display boards

6 In 2010 and 2015, what best describes the time frame of production targets at this establishment? Mark one box for each year

Examples of production targets are: production, quality, efficiency, waste, on-time delivery.

Main focus was on short-term (less than one year) production targets

Main focus was on long-term (more than one year) production targets

Combination of short-term and long-term production targets

No production targets (If no production targets in both years, SKIP to (13)

7 In 2010 and 2015, how easy or difficult was it for this establishment to achieve its production targets?

Possible to achieve without much effort

Possible to achieve with some effort

Possible to achieve with normal amount of effort

Possible to achieve with more than normal effort

Only possible to achieve with extraordinary effort 
8 In 2010 and 2015, who was aware of the production targets at this establishment?

Mark one box for each year

\begin{tabular}{l|l}
2010 & 2015 \\
\hline
\end{tabular}

Only senior managers

Most managers and some production workers

Most managers and most production workers

All managers and most production workers

9 In 2010 and 2015, what were non-managers' performance bonuses usually based on at this establishment? Mark all that apply

\begin{tabular}{|l|l|}
\hline 2010 & 2015 \\
\hline
\end{tabular}

Their own performance as measured by production targets

Their team or shift performance as measured by production targets

Their establishment's performance as measured by production targets

Their company's performance as measured by production targets

No performance bonuses (If no performance bonuses in both years, SKIP to (11)

10 In 2010 and 2015, when production targets were met, what percent of non-managers at this establishment received performance bonuses?

Mark one box for each year

\begin{tabular}{l|r}
2010 & 2015
\end{tabular}

$0 \%$

$1-33 \%$

$34-66 \%$

$67-99 \%$

$100 \%$

Production targets not met

11 In 2010 and 2015, what were managers' performance bonuses usually based on at this establishment?

Mark all that apply

\begin{tabular}{l|l}
2010 & 2015
\end{tabular}

Their own performance as measured by production targets

Their team or shift performance as measured by production targets

Their establishment's performance as measured by production targets

Their company's performance as measured by production targets

No performance bonuses (If no performance bonuses in both years, SKIP to (13) 
If not shown, please enter your 11-digit Census File

Number (CFN) from the mailing address.

12 In 2010 and 2015, when production targets were met, what percentage of managers at this establishment received performance bonuses?

Mark one box for each year

$0 \%$

$1-33 \%$

$34-66 \%$

$67-99 \%$

$100 \%$

Production targets not met

13 In 2010 and 2015, what was the primary way non-managers were promoted at this establishment?

Mark one box for each year

\begin{tabular}{l|l}
2010 & 2015
\end{tabular}

Promotions were based solely on performance and ability

Promotions were based partly on performance and ability, and partly on other factors (for example, tenure or family connections)

Promotions were based mainly on factors other than performance and ability (for example, tenure or family connections)

Non-managers are normally not promoted

14

In 2010 and 2015, what was the primary way managers were promoted at this establishment?

Mark one box for each year

Promotions were based solely on performance and ability

Promotions were based partly on performance and ability, and partly on other factors (for example, tenure or family connections)

Promotions were based mainly on factors other than performance and ability (for example, tenure or family connections)

Managers are normally not promoted

15 In 2010 and 2015, when was an under-performing non-manager reassigned or dismissed at this establishment?

Mark one box for each year

Within 6 months of identifying non-manager under-performance

After 6 months of identifying non-manager under-performance

Rarely or never

10

In 2010 and 2015, when was an under-performing manager reassigned or dismissed at this establishment?

Within 6 months of identifying manager under-performance

After 6 months of identifying manager under-performance

Rarely or never 
17 Was the headquarters for this company at the same location as this establishment?

Mark one box for each year

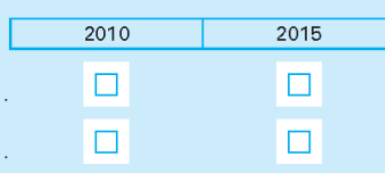

No

If no, what state (if in the US) or country (if abroad)?

18 In 2010 and 2015, where were decisions on hiring permanent full-time employees made for this establishment?

Mark one box for each year

\begin{tabular}{|l|l|}
\hline 2010 & 2015 \\
\hline
\end{tabular}

Only at this establishment

Only at headquarters

Both at this establishment and at headquarters

Other (please specify)

19 In 2010 and 2015, whe this establishment?

Mark one box for each year

$\square$

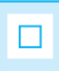

Only at this establishment

Only at headquarters

Both at this establishment and at headquarters

Other (please specify)

20 In 2010 and 2015, where were decisions on new product introductions made for this establishment?

Mark one box for each year

\begin{tabular}{|l|l|}
\hline 2010 & 2015 \\
\hline
\end{tabular}

Only at this establishment

Only at headquarters

Both at this establishment and at headquarters

Other (please specify)

21 In 2010 and 2015, where were product pricing decisions made for this establishment?

Mark one box for each year

Only at this establishment

Only at headquarters

Both at this establishment and at headquarters

Other (please specify)
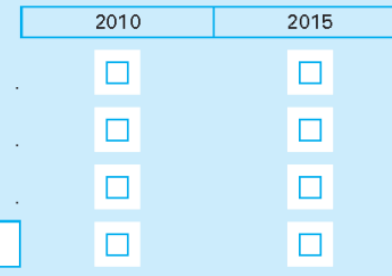
If not shown, please enter your 11-digit Census File

Number (CFN) from the mailing address.

22 In 2010 and 2015, where were advertising decisions for products made for this establishment?

Mark one box for each year

Only at this establishment

Only at headquarters

Both at this establishment and at headquarters

Other (please specify)

23 In 2010 and 2015, what was the dollar amount that could be used to purchase a fixed/capital asset for this establishment without prior authorization from headquarters?

Mark one box for each year

\begin{tabular}{l|l}
2010 & 2015
\end{tabular}

Under $\$ 1,000$

$\$ 1,000$ to $\$ 9,999$

$\$ 10,000$ to $\$ 99,999$

$\$ 100,000$ to $\$ 999,999$

$\$ 1$ million or more

Section C - Data and Decision Making

24 In 2010 and 2015, what best describes the availability of data to support decision making at this establishment?

Mark one box for each year

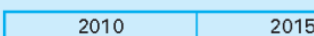

Data to support decision making are not available

A small amount of data to support decision making is available

A moderate amount of data to support decision making is available

A great deal of data to support decision making is available

All the data we need to support decision making is available

25 In 2010 and 2015, what best describes the use of data to support decision making at this establishment?

Mark one box for each year

Decision making does not use data

Decision making relies slightly on data

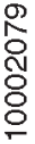

Decision making relies moderately on data

Decision making relies heavily on data

Decision making relies entirely on data

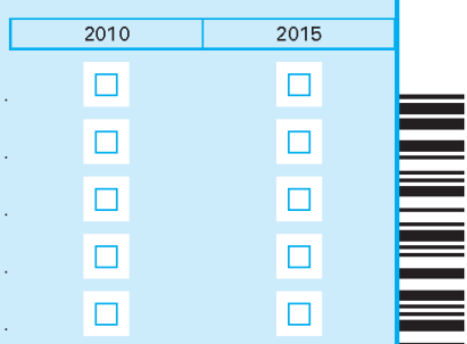

CONTINUE ON PAGE 8 
Form MP-10002 (03-02-2016)

20 In 2010 and 2015, who chose what type of data to collect at this establishment?

Mark all that apply

\begin{tabular}{l|l}
2010 & 2015
\end{tabular}

Managers at this establishment

Managers at headquarters and/or other establishments

Production workers

Engineers

Customers

Government regulations or agencies

27 a) Consider each of the following sources of data and rate how frequently each source was used in decision making at this establishment in $\mathbf{2 0 1 5}$

Mark all that apply

Performance indicators from production technology or instruments

Formal or informal feedback from managers

Formal or informal feedback from production workers

Data from outside the firm (suppliers, customers, outside data providers)

\begin{tabular}{c|c|c|c|c}
\hline Daily & Weekly & Monthly & Yearly & Never \\
$\square$ & $\square$ & $\square$ & $\square$ & $\square$ \\
$\square$ & $\square$ & $\square$ & $\square$ & $\square$ \\
$\square$ & $\square$ & $\square$ & $\square$ & $\square$ \\
$\square$ & $\square$ & $\square$ & $\square$ & $\square$ \\
\hline
\end{tabular}

b) Now think back to five years ago. How frequently was each source of data used in decision making at this establishment in $\mathbf{2 0 1 0}$ ?

\section{Mark all that apply}

Performance indicators from production technology or instruments

Formal or informal feedback from managers

Formal or informal feedback from production workers.

Data from outside the firm (suppliers, customers, outside data providers)

\begin{tabular}{c|c|c|c|c} 
Daily & Weekly & Monthly & Yearly & Never \\
$\square$ & $\square$ & $\square$ & $\square$ & $\square$ \\
$\square$ & $\square$ & $\square$ & $\square$ & $\square$ \\
$\square$ & $\square$ & $\square$ & $\square$ & $\square$ \\
$\square$ & $\square$ & $\square$ & $\square$ & $\square$
\end{tabular}

28 a) How frequently was each of these activities influenced by data analysis at this establishment in $\mathbf{2 0 1 5}$ ?

Mark all that apply

Design of new products or services

Demand forecasting

Supply chain management

b) Now think back to five years ago. How frequently was each of these activities influenced by data analysis at this establishment in $\mathbf{2 0 1 0}$ ?

\section{Mark all that apply}

Design of new products or services

Demand forecasting

Supply chain management

\begin{tabular}{c|c|c|c|c}
\hline Daily & Weekly & Monthly & Yearly & Never \\
$\square$ & $\square$ & $\square$ & $\square$ & $\square$ \\
$\square$ & $\square$ & $\square$ & $\square$ & $\square$ \\
$\square$ & $\square$ & $\square$ & $\square$ & $\square$
\end{tabular}

CONTINUE ON PAGE 
If not shown, please enter your 11-digit Census File

Number (CFN) from the mailing address.

29 How frequently does this establishment typically rely on predictive analytics (statistical models that provide forecasts in areas such as demand, production, or human resources)?

Mark all that apply

Daily

Weekly

Monthly

Yearly

Never

\section{Section D - Uncertainty}

The following examples illustrate how a plant could complete the type of questions asked in this section. All examples are fictional. If your forecasts do not include the level of detail requested or do not exist, please report according to your best judgment. Estimates are acceptable.

Example A: Jane Doe is filling out this survey for Plant A. In 2015 , Plant A had approximately $\$ 4,500,000$ in products shipped, with a forecast of $\$ 4,750,000$ in 2016 .

For calendar years 2015 and 2016, what are the approximate dollar values of products shipped, including interplant transfers, exports and other receipts at this establishment? Exclude freight charges and excise taxes.

For 2015 calendar year

Estimate for 2016 calendar year

\begin{tabular}{|c|c|c|c|c|}
\hline \$Bil. & Mil. & \multicolumn{3}{|c|}{ Thou. } \\
\hline & 4 & 5 & 0 & 0 \\
\hline & 4 & 7 & 5 & 0 \\
\hline
\end{tabular}

Example B: Jane also knows that business at Plant A is forecasted to grow approximately an additional $5 \%$ in 2017. with predicted annual value of products shipped of $\$ 5$ million. However, Jane knows there is some uncertainty with that forecast and that the value of products shipped next year could be more or less than $\$ 5$ million depending on consumer demand, price of materials, and other uncertainties in the market. Given this uncertainty, this is how Jane

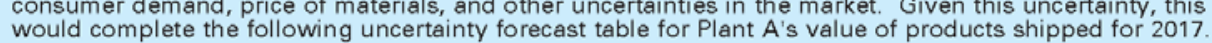

Looking ahead to the 2017 calendar year, what is the approximate dollar value of products shipped you would anticipate for this establishment in the following scenarios, and what likelihood do you assign to each scenario?

\begin{tabular}{|c|c|c|c|c|c|c|c|c|}
\hline \multirow{3}{*}{$\begin{array}{c}2017 \text { scenarios, } \\
\text { from lowest to } \\
\text { highest }\end{array}$} & \multicolumn{4}{|c|}{$\begin{array}{l}\text { Approximate dollar value of } \\
\text { shipments in } 2017\end{array}$} & \multirow{2}{*}{\multicolumn{4}{|c|}{$\begin{array}{l}\text { Percentage likelihood } \\
\text { (values in this column } \\
\text { should sum to } 100 \text { ) }\end{array}$}} \\
\hline & \multirow[t]{2}{*}{ \$Bil. } & Mil. & \multicolumn{2}{|c|}{ Thou. } & & & & \\
\hline & & 2 & 80 & 0 & & & 5 & $\%$ \\
\hline LOW & & 4 & 20 & 0 & & 1 & 0 & $\%$ \\
\hline MEDIUM & & 5 & 00 & 0 & & 6 & 0 & $\%$ \\
\hline $\mathrm{HIGH}$ & & 6 & 30 & 0 & & 2 & 0 & $\%$ \\
\hline HIGHEST & & 7 & 50 & 0 & & & 5 & $\%$ \\
\hline & & & & al & 1 & 0 & 0 & $\%$ \\
\hline
\end{tabular}


30 For calendar years 2015 and 2016, what are the approximate dollar values of products shipped, including interplant transfers, exports and other receipts at this establishment? Exclude freight charges and excise taxes.

For 2015 calendar year

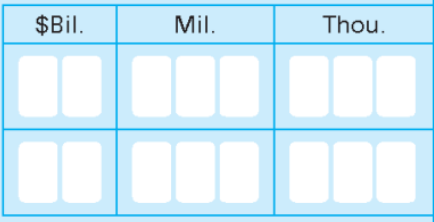

Estimate for 2016 calendar year

31 Looking ahead to the 2017 calendar year, what is the approximate dollar value of products shipped you would anticipate for this establishment in the following scenarios, and what likelihood do you assign to each scenario?

\begin{tabular}{|c|c|c|c|c|c|c|c|}
\hline \multirow{3}{*}{$\begin{array}{c}2017 \text { scenarios, } \\
\text { from lowest to } \\
\text { highest } \\
\text { LOWEST }\end{array}$} & \multicolumn{3}{|c|}{$\begin{array}{l}\text { Approximate dollar value of } \\
\text { shipments in } 2017\end{array}$} & \multirow{2}{*}{\multicolumn{4}{|c|}{$\begin{array}{l}\text { Percentage likelihood } \\
\text { (values in this column } \\
\text { should sum to } 100 \text { ) }\end{array}$}} \\
\hline & \$Bil. & Mil. & Thou. & & & & \\
\hline & & & & & & & $\%$ \\
\hline LOW & & & & & & & $\%$ \\
\hline MEDIUM & & & & & & & $\%$ \\
\hline $\mathrm{HIGH}$ & & & & & & & $\%$ \\
\hline HIGHEST & & & & & & & $\%$ \\
\hline & & & Tot & 1 & 0 & 0 & $\%$ \\
\hline
\end{tabular}

32 For calendar years 2015 and 2016, what are the approximate dollar values of capital expenditures for new and used depreciable assets at this establishment? Include buildings and other structures, machinery and equipment. Exclude land.

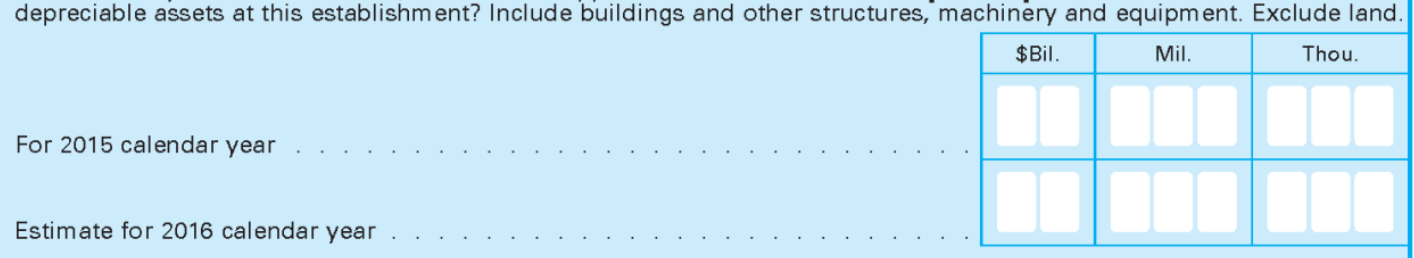

은
ㄱ.
$\stackrel{8}{\circ}$ 
Form MP-10002 (03-02-2016)

If not shown, please enter your 11-digit Census File

Number (CFN) from the mailing address.

33 Looking ahead to the 2017 calendar year, what is the approximate dollar value of capital expenditures you would anticipate for this establishment in the following scenarios, and what likelihood do you assign to each scenario?

\begin{tabular}{|c|c|c|c|c|c|c|c|}
\hline \multirow{3}{*}{$\begin{array}{c}2017 \text { scenarios, } \\
\text { from lowest to } \\
\text { highest } \\
\text { LOWEST }\end{array}$} & \multicolumn{3}{|c|}{$\begin{array}{c}\text { Approximate dollar value of capital } \\
\text { expenditures in } 2017\end{array}$} & \multirow{2}{*}{\multicolumn{4}{|c|}{$\begin{array}{l}\text { Percentage likelihood } \\
\text { (values in this column } \\
\text { should sum to } 100 \text { ) }\end{array}$}} \\
\hline & \$Bil. & \multicolumn{2}{|l|}{ Mil. } & & & & \\
\hline & & & & & & & $\%$ \\
\hline LOW & & & & & & & $\%$ \\
\hline MEDIUM & & & & & & & $\%$ \\
\hline $\mathrm{HIGH}$ & & & & & & & $\%$ \\
\hline HIGHEST & & & & & & & $\%$ \\
\hline & & & Total & 1 & 0 & 0 & $\%$ \\
\hline
\end{tabular}

34 For the following dates, what was the total number of employees (full-time plus part-time) on the payroll at this establishment? Exclude full- or part-time leased employees whose payroll was filed by an employee leasing company, temporary staffing obtained from a staffing service, and purchased professional and technical services.

On March 12, 2015

On March 12, 2016

35 Looking ahead, approximately how many employees would you anticipate on this establishment's payroll as of March 12, 2017 in the following scenarios, and what likelihood do you assign to each scenario?

\begin{tabular}{|c|c|c|c|c|c|}
\hline $\begin{array}{l}2017 \text { scenarios, } \\
\text { from lowest to } \\
\text { highest }\end{array}$ & $\begin{array}{c}\text { Approximate number of } \\
\text { employees on payroll as } \\
\text { of March } 12,2017\end{array}$ & & $\begin{array}{l}\text { reer } \\
\text { alue } \\
\text { hou }\end{array}$ & $\begin{array}{l}\text { tag } \\
\text { in } \\
d s\end{array}$ & $\begin{array}{l}\text { likelihood } \\
\text { is column } \\
\text { to } 100 \text { ) }\end{array}$ \\
\hline LOWEST & & & & & $\%$ \\
\hline LOW & & & & & $\%$ \\
\hline MEDIUM & & & & & $\%$ \\
\hline $\mathrm{HIGH}$ & & & & & $\%$ \\
\hline HIGHEST & & & & & $\%$ \\
\hline & Tote & 1 & 0 & 0 & $\%$ \\
\hline
\end{tabular}


36 For calendar years 2015 and 2016, what are the approximate dollar expenditures for this establishment on materials, parts, containers, and packaging?

For 2015 calendar year

Estimate for 2016 calendar year

\begin{tabular}{|c|c|c|}
\hline \$Bil. & Mil. & Thou. \\
\hline & & \\
\hline & & \\
\hline & & \\
\hline
\end{tabular}

37 Looking ahead to the 2017 calendar year, what are the approximate dollar expenditures on materials, parts, containers, and packaging you would anticipate for this establishment in the following scenarios, and what likelihood do you assign to each scenario?

\begin{tabular}{|c|c|c|c|c|c|c|c|}
\hline \multirow{3}{*}{$\begin{array}{c}2017 \text { scenarios, } \\
\text { from lowest to } \\
\text { highest } \\
\text { LOWEST }\end{array}$} & \multicolumn{3}{|c|}{$\begin{array}{c}\text { Approximate dollar cost of } \\
\text { materials, parts, containers, anc } \\
\text { packaging in } 2017\end{array}$} & \multirow{2}{*}{\multicolumn{4}{|c|}{$\begin{array}{l}\text { Percentage likelihood } \\
\text { (values in this column } \\
\text { should sum to } 100 \text { ) }\end{array}$}} \\
\hline & \multirow[t]{2}{*}{ \$Bil. } & \multirow[t]{2}{*}{ Mil. } & Thou. & & & & \\
\hline & & & & & & & $\%$ \\
\hline LOW & & & & & & & $\%$ \\
\hline MEDIUM & & & & & & & $\%$ \\
\hline $\mathrm{HIGH}$ & & & & & & & $\%$ \\
\hline HIGHEST & & & & & & & $\%$ \\
\hline & & & Tot & 1 & 0 & 0 & $\%$ \\
\hline
\end{tabular}

Section E - Background Characteristics

38 What year did you start working at this establishment?

39 What was the number of managers at this establishment for the pay periods including March 12,2010 and March 12, 2015?

A manager is someone who has employees directly reporting to them, with whom they meet on a regular basis, and whose pay and promotion they may be involved with, e.g., Plant Manager, Human Resource Manager, Quality Manager

Number of managers at this establishment (Estimates are acceptable)

\begin{tabular}{|l|l|}
\hline 2010 & 2015 \\
\hline & \\
\hline & \\
\hline
\end{tabular}

CONTINUE ON PAGE 13 
If not shown, please enter your 11-digit Census File

Number (CFN) from the mailing address.

40 In 2010 and 2015, what was the percent of managers at this establishment with a bachelors degree?

Mark one box for each year

$20 \%$ or less

$21-40 \%$

$41-60 \%$

$61-80 \%$

More than $80 \%$

41 In 2010 and 2015, what was the percent of non-managers at this establishment with a bachelors degree?

Mark one box for each year

$0 \%$

$1-10 \%$

$11-20 \%$

More than $20 \%$

42

In 2010 and 2015, what percent of all employees at this establishment were members of a labor union?

Mark one box for each year

\begin{tabular}{|l|l|}
\hline 2010 & 2015 \\
\hline
\end{tabular}

$0 \%$

$1-20 \%$

$21-40 \%$

$41-60 \%$

$61-80 \%$

More than $80 \%$

43 In 2010 and 2015, what percent of all employees at this establishment could be classified in the following ways?

Estimates are acceptable.

Employees who were part-time

Employees who were working flexible hours

Employees who worked from home one day or more per week

Employees who were cross-trained

\begin{tabular}{|l|l|l|l|l|l|}
\hline \multicolumn{2}{|c|}{2010} & \multicolumn{2}{|c|}{2015} & \\
\hline & $\%$ & & & $\%$ & \\
\hline & $\%$ & & & $\%$ & \\
\hline & $\%$ & & & $\%$ \\
\hline & & & \\
\hline & & & & & \\
\hline & & & & \\
\hline
\end{tabular}


44 In 2010 and 2015, which of the following best described the production of this establishment?

Mark one box for each year

Job shop

Batch production

Cellular manufacturing

Continuous flow (other than cellular manufacturing)

Research and development or prototyping

45 Is this establishment owned $50 \%$ or more by its founder(s) or member(s) of a founder's family? Mark one box

Yes, founder(s) owns it

Yes, member(s) of a founder's family owns it (e.g., daughter, son, sister, brother)

No

If yes to either of the above, is the CEO of the firm also a founder or a member of a founder's family?

Yes

No

40 Is

s this establishment part of a firm which has production establishments in other countries?

Yes

No

REMARKS (Please use this space for any explanations that may be essential in understanding your reported data.)

。

CERTIFICATION - This report is substantially accurate and was prepared in accordance with the instructions. Is the time period covered by this report a calendar year?

$\square$ Yes $\square$ No-Enter time period covered $\longrightarrow$ FROM

\begin{tabular}{l|l|l} 
Month & Year & \\
\hline & & TO
\end{tabular}

TO

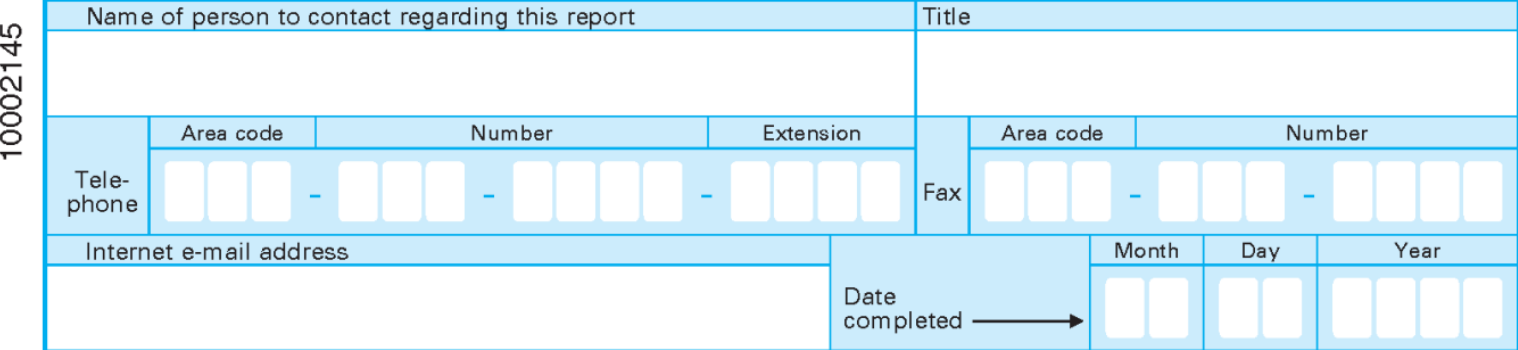

Thank you for completing your 2015 MANAGEMENT AND ORGANIZATIONAL PRACTICES form. PLEASE PHOTOCOPY THIS FORM FOR YOUR RECORDS AND RETURN THE ORIGINAL. 